\title{
A BAF-2 fúrás töréses szerkezeti elemeinek mikroszerkezeti és cementáció vizsgálata (Bodai Agyagkő Formáció)
}

\author{
HrabovsZki Ervin*, Tóth Emese, RAucsik Béla, VARGa Andrea, Schubert Félix \\ SZTE TTIK Ásványtani, Geokémiai és Kőzettani Tanszék, 6722 Szeged, Egyetem utca 2. \\ *levelező szerző, e-mail: ervin.hrabovszki@gmail.com
}

\section{Microstructure and cementation analyses on core samples from the BAF-2 well (Boda Claystone Formation, Mecsek Mts)}

\begin{abstract}
The Boda Claystone Formation, which is a potential host rock for a high-level nuclear waste repository, is located in the Mecsek Mts (SW Hungary). Since this formation is characterized by low porosity and permeability the fluid flow occurs through fractures and structural inhomogenities. The aim of this study is to determine the microstructure of the structural elements caused by major deformation events. Morphological, textural and mineralogical analyses were carried out on core samples from borehole BAF-2. A total of fifty-six samples were collected from a 74.34-899.22 m depth interval, which covers almost the true vertical depth of the borehole. The mineralogical composition of vein-filling minerals was analysed by polarizing microscopy, X-ray fluorescence spectroscopy and Raman microspectroscopy. The dip angles of the veins were determined using stitched core scanner images. These dip values were corrected by the measured tilt of the well. According to the observations made for this study, veins from borehole BAF-2 can be divided into six groups based on their mineralogical composition, growth morphology and average dip angle. The dominant veinfilling minerals are calcite and anhydrite with small amounts of albite, celestine, quartz, baryte and pyrite, respectively. The growth morphology can be syntaxial, antitaxial and ataxial as well. The dip values define three groups with, respectively, $22^{\circ}, 42^{\circ}$ and $70^{\circ}$ average values. Given the dip angle distribution and microstructure analyses deformation history and palaeofluid flow events might have been more complex than once thought.
\end{abstract}

Keywords: fracture cementation, dip angle distribution, vein-filling minerals, vein geometry, microstructure

Összefoglalás

A Nyugati-Mecsekben elhelyezkedő Bodai Agyagkő Formáció (BAF) a nagy aktivitású radioaktív hulladékok elhelyezésére szolgáló, mélygeológiai tároló potenciális befogadó képződménye. Mivel a BAF porozitása és permeabilitása extrém kicsi, így abban fluidumáramlási útvonalak törések, szerkezeti inhomogenitások mentén jöhetnek létre. Ebből adódóan kiemelkedően fontos a BAF deformációtörténetének megismerése, melyről a repedések, repedésrendszerek hordoznak információt. Kutatásunk során a Boda község közelében mélyült BAF-2 fúrás 74,34-899,22 m közötti mélységtartományából származó 56 db fúrómagminta szerkezeti elemeinek morfológiai és ásványtani vizsgálatát végeztük el, továbbá a repedéskitöltések belső mikroszerkezetét értelmeztük. Az egyes repedésgenerációk cementfázisainak összetételét polarizációs mikroszkópos megfigyelések, röntgenfluoreszcens spektrometria és Raman mikrospektroszkópia segítségével elemeztük. A magpalástról készített felvételek alapján az ereket $22^{\circ}, 42^{\circ}$ és $70^{\circ}$ átlagos dőlésszögú csoportba soroltuk. A repedéskitöltéseket ásványtani alapon két kategóriába osztottuk. Az első kategóriába sorolható erek dominánsan kalcit kitöltésúek, azonban a másodlagos repedéskitöltő ásványtársulások mintánként eltéróen albit, albit-cölesztin, valamint kvarc-pirit lehetnek. A vizsgált repedéskitöltések második csoportjában kalcitanhidrit a domináns kitöltő ásványegyüttes, amely mellett másodlagosan kvarc-barit-cölesztin, valamint albit-piritcölesztin jelenik meg. A repedéskitöltések szöveti elemzése során szintaxiális, antitaxiális és ataxiális növekedési morfológiával rendelkező ereket különböztettünk meg. Az ásványtani alapon közös kategóriába sorolható értípusok orientációbeli, valamint szöveti tulajdonságaik alapján azonban markánsan eltérő deformációs és fluidumáramlási eseményeket jeleznek.

Tárgyszavak: repedéscementáció, dólésszög eloszlás, repedéskitöltő ásványok, érgeometria, mikroszerkezet 


\section{Bevezetés, elózmények}

A hazai nagy aktivitású és hosszú élettartamú radioaktív hulladékok végleges elhelyezése mélységi geológiai tároló telephelyének kijelölését teszi szükségessé. Ebből adódóan a kiégett nukleáris fútőanyag és a nagy aktivitású radioaktív hulladékok végleges elhelyezésére hazánkban több évtizede folyik kiterjedt tudományos kutatás (pl. BÁRDOSSY 1995, 1998, 1999; ÁrKAI et al. 2000; KonRÁD \& HÁMOS 2006; VARGA et al. 2006; HegYháti 2007; FEDOR et al. 2008, Konrád et al. 2010; Halász 2011; Máthé \& VARGa 2012; MÁTHÉ 2015; KeREKI 2016). A megfelelő tároló telephelyének célzott földtani kutatása a Nyugati-Mecsekben az 1990-es évek óta folyik a Bodai Agyagkő (korábbi nevén Bodai Aleurolit, a továbbiakban BAF) Formációban (1. ábra), habár az uránérc bányászatának köszönhetően már a nyolcvanas években felvetődött, hogy a BAF számbavehetô képződmény lehet radioaktívhulladék-tároló befogadására. A BAF, mint potenciális befogadó képződmény az agyagjellegú befogadó közeg kategóriába sorolható (KonRÁD \& HÁmos 2006). MAZUREK et al. (2003) alapján a szilárd, előrehaladott konszolidációs fokon álló, de agyagtulajdonságaikat még megőrző aleurolitok, agyagkövek a nukleáris hulladékok végleges elhelyezése szempontjából számba- vehető agyagjellegû képződmények egyik kiemelkedő fontosságú csoportját alkotják. Erre a csoportra többek között a nagyfokú homogenitás, az alacsony vízáteresztő képesség, a képlékeny deformációra való hajlam, továbbá a repedések öngyógyuló képessége jellemző. A befogadó kőzet alkalmassága ugyanakkor nagymértékben függ a fluidumáramlási folyamatoktól. Mivel a BAF-ra extrém kis porozitás (maximum $3 \%$ ) és permeabilitás $\left(<10^{-18}-10^{-21} \mathrm{~m}^{2}\right)$ jellemző (FEDOR et al. 2008), így áramlási útvonalak jellemzően törésekhez, szerkezeti inhomogenitásokhoz kötődhetnek (MAROs 2006). Ennél fogva elengedhetetlen a képződmény szerkezeti képének megismerése, a repedések menti, egykori áramlási folyamatok értelmezése. Ebben a vonatkozásban ÁRKAI et al. (2000) számos anyagvizsgálati módszer (többek között fluidumzárvány vizsgálatok, stabilizotópmérések, elektronmikroszonda- és röntgen-pordiffraktometriás vizsgálatok) alkalmazásával jellemezték a repedéskitöltéseket. Mindezen kulcsfontosságú ismeretek mellett azonban a korábbi kutatások nem érintették részletesen az erek makroszkópos és mikroszkópos morfológiáját, a képzôdési mechanizmusok lehetséges típusait, ugyanakkor a szerkezetfejlődés pontosabb megismeréséhez ennek vizsgálatával fontos információkhoz juthatunk. Az erek makroszkópos morfológiájának, a felépítő kristályok alakjának,

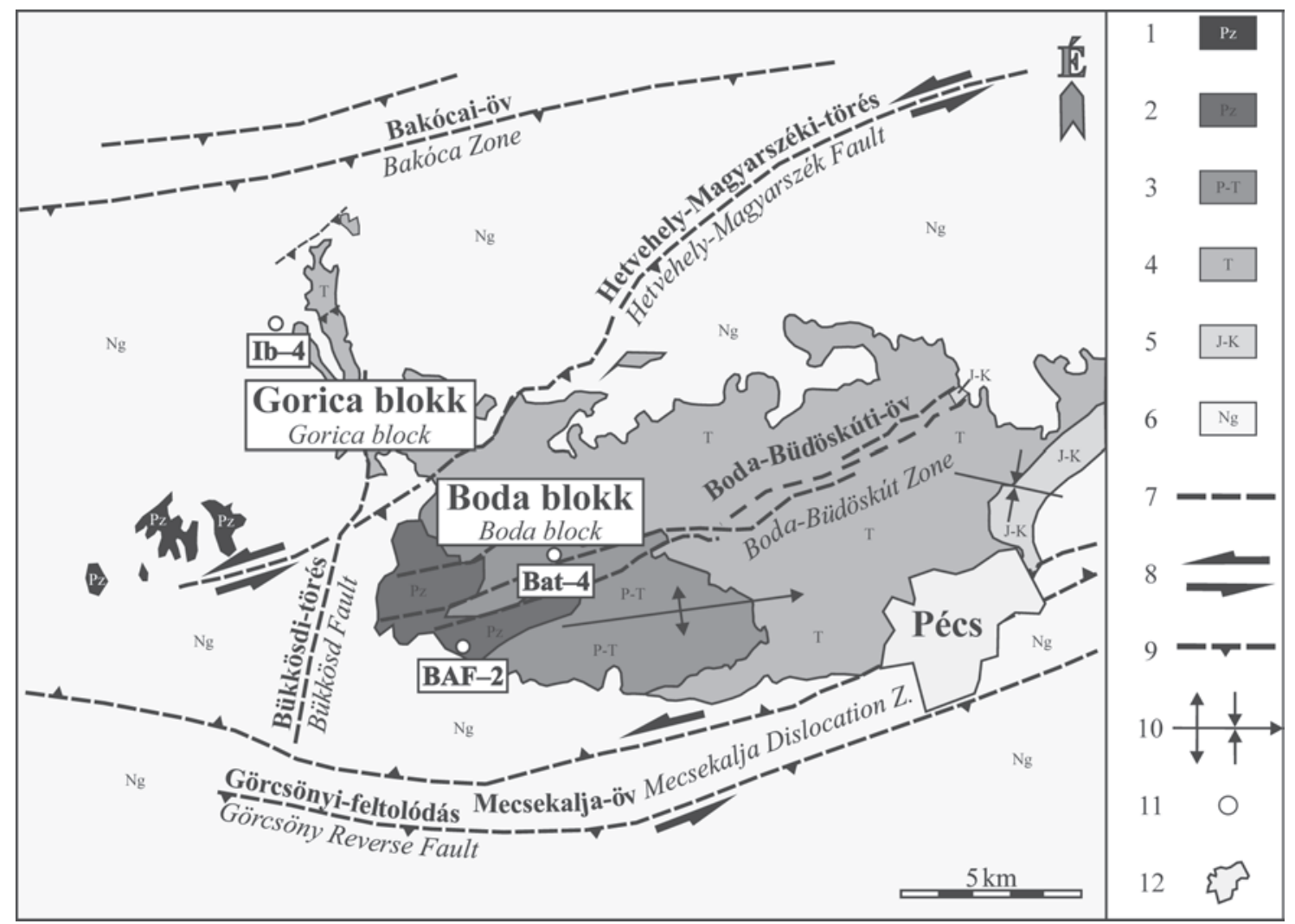

1. ábra. A Bodai Agyagkő Formáció elterjedési területe (KoNRÁD \& SEBE 2010, módosítva)

Jelmagyarázat: 1 - paleozoos képződmények általában; 2 - felső-permi Bodai Agyagkő Formáció; 3 - felső-permi Kővágószőlősi Homokkő Formáció; 4 - triász üledékes közetek (homokkövek, karbonátok, evaporitok); 5 - jura és kréta üledékes kőzetek, kréta vulkanitok; 6 - neogén képződmények; 7 - vető; 8 oldaleltolódás; 9 - áttolódás; 10 - szinklinális és antiklinális; 11 - fúráspont; 12 - település

Figure 1. Distribution of the Boda Claystone Formation (modified after KONRÁD \& SEBE 2010)

Legend: 1 - Palaeozoic in general; 2 - Upper Permian Boda Claystone Fm; 3 - Upper Permian Kövágószölös Sandstone Fm; 4 - Triassic sediments (sandstones, carbonates, evaporites); 5 - Jurassic and Cretaceous sediments and Cretaceous volcanite; 6 - Neogene sediments; 7 - fault; 8 - strike-slip fault; 9 - thrust fault; 10 - syncline and anticline; 11 - well site; 12 - settlement 
valamint az erek növekedési mechanizmusának részletes leírásával lehetőségünk nyílik a képződményt ért alakváltozás elemzésére, valamint az egykori áramlási folyamatok alaposabb megismerésére.

Az érképződés két alapvető anyagtranszport folyamatának egyike a diffúzió. A szállítódáshoz ilyen módon nem szükséges a folyadék mozgása, akár teljesen stagnáló közegben is végbe mehet (Bons 2000). Ebben az esetben az oldott anyagban kémiai potenciálgradiens áll fenn — amely diffúziót okoz, és anyagvándorláshoz vezet — így a fluidum egy összefüggő pályát szolgáltat a szállítódáshoz. A diffúzió földtani szempontból nagyon fontos anyagtranszport mechanizmus, az oldódás-kicsapódás és a metamorf reakciók elsődleges eszköze. Jóllehet a diffúzió rövid távon ( $<\mathrm{cm}-\mathrm{dm})$ igen hatékony, azonban nagyobb távolságú transzport szempontjából kedvezőtlen mechanizmus. A másik alapvető mobilizációs mechanizmus a fluidumáramlás. Ekkor a folyadék áramlása az oldott anyagokkal együtt történik. A vizes fluidumok a kőzetekhez képest igen kis viszkozitással rendelkeznek, ezáltal a földtani közegben egyszerúen és gyorsan nagy távolságokat képesek megtenni (Bons et al. 2012). A fluidumáramlás az oldott anyagok egyetlen hatékony, nagy távolságokat $(>\mathrm{m}-\mathrm{km})$ érintő, kőzeteken át ható transzportfolyamata. A fluidumok áramlásának két típusát különböztethetjük meg: (1) fluidumáramlás csatornákon keresztül (pl. törések), permeábilis közegben történő áramlás (advektív áramlás), (2) fluidumáramlás a fluidumot tartalmazó törésekkel együtt (mobile hydrofractures). Az advektív fluidumáramlás — amelyet a hidraulikus nyomásgradiens hajt — döntő része összefüggő csatornákon keresztül történik. Ezek a csatornák makroszkopikus léptékú törések vagy akár pórusok is lehetnek a permeabilis kőzetben (pervasive flow). A lokalizált csatornákhoz (törésekhez) kötött áramlásban a fluidum a kőzettérfogat többségével nem érintkezik, míg az átható áramlás során a kőzet túlnyomó részével kapcsolatba kerül, aminek jelentős szerepe van a víz-kőzet kölcsönhatások szempontjából. Mozgó hidraulikus törések (mobile hydrofractures) esetében a repedések terjedése és a fluidum áramlása egyidejûleg történik, megegyező sebességgel. A szállítódás sebessége ebben az esetben nem írható le a Darcy-törvénnyel. Az áramlás igen gyors (m/s nagyságrendû), de megszakításokkal múködő. Rövid aktivitás után jellemzően hosszú stagnálási időszak — vagy esetleg más típusú áramlás — következik. A szállítódás során nem lép fel jelentős kölcsönhatás a mellékkôzet és a fluidum között. A mozgó hidraulikus törések tehát a fluidum gyors, nagy távolságokra történő áramlását teszik lehetôvé (Bons 2000, Bons et al. 2012).

A repedések sajátos mikroszövetét a növekedési verseny határozza meg. A különböző kristályfelületek eltérő növekedési rátával rendelkeznek, aminek hatására a növekvő szemcsék határai nem minden esetben meróleges helyzetben fejlődnek a törés síkjára, így a növekedés szempontjából kedvező és kedvezőtlen orientációk jönnek létre (BoNS 2001). Szintaxiálisnak nevezzük azt a növekedési morfológiát, amely kialakulása során a kristályok a mellékkőzet falai felől a repedés közepe felé növekednek (2. ábra, A). A

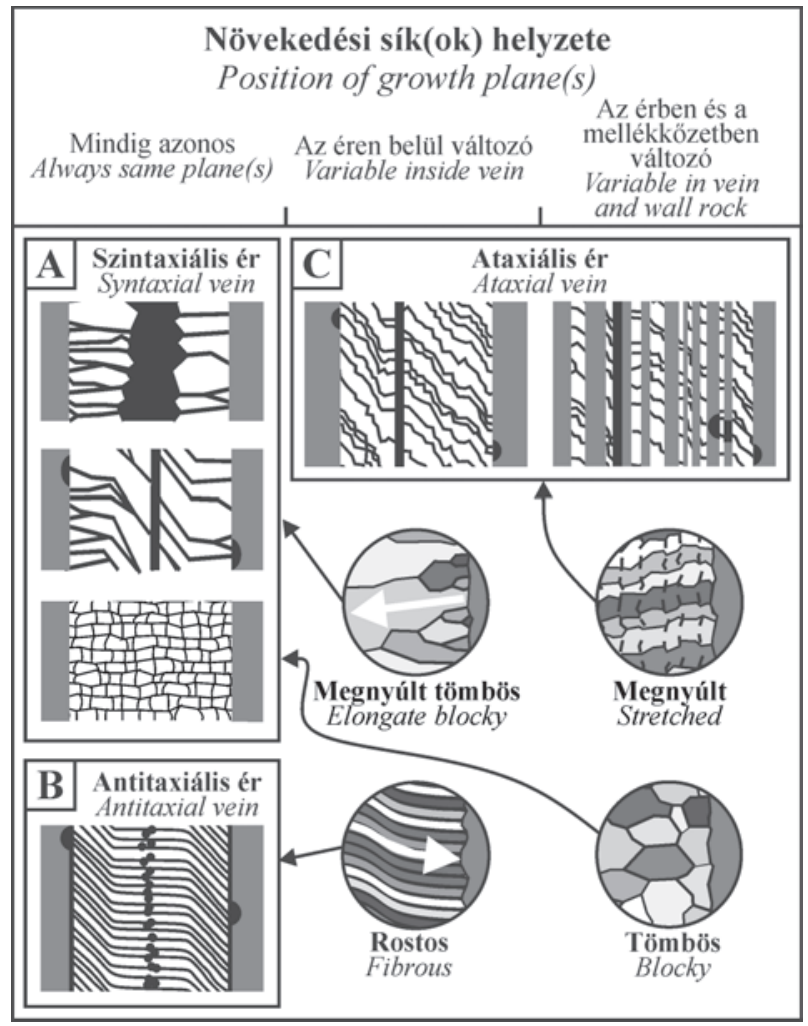

2. ábra. Értípusok és jellemző mikroszövetük a növekedési sík(ok) helyzetének tükrében (Bons et al. 2012, módosítva)

A - szintaxiális ér; B - antitaxiális ér; C - ataxiális ér. A négyzetes ábrák sematikusan szemléltetik az értípusokat, míg a körábrák az egyes erek belső kristálymorfológiáját (érszövetét) részletesen, nagy nagyitásban mutatják be. A fehér nyilak a kristályok növekedési irányát jelölik

Figure 2. Basic vein types (A - syntaxial; $B$ - antitaxial; $C$ - ataxial) with their internal crystal morphology and position of the growth plane(s) (modified after Bons et al. 2012)

The square shape figures schematically illustrate the basic vein types, while illustrations in the circles show their internal crystal morphology (vein microtexture) at high magnification. The white arrows show the growth direction of the crystals

folyamat során szimmetrikus kitöltés keletkezik, amely közepén az ellentétes oldalról közeledő kristályok találkoznak (3. ábra, B). A jellemző szövettípust tömbös, valamint megnyúlt tömbös kristályok alkotják. A megnyúlt tömbös szemcsealak keletkezése az egyes kristályok egymáson történő túlnövekedésével mehet végbe (2. ábra, A), míg a tömbös kialakulása a felnyílási térbe áramló fluidumból közvetlenül történik (3. ábra, A; HILGERS \& URAI 2002). Az ilyen típusú érszövet a szülőfluidum advektív áramlására utal (Bons 2000).

Antitaxiális növekedés alkalmával a kristályok növekedése a felnyílási tér közepe felől a mellékkőzet falai felé irányul (HILGERS \& URAI 2002). Az eret alkotó kristályok optikai folytonossággal helyezkednek el a repedéskitöltés két oldala között, és egy középső varratból növekednek a mellékkőzet irányába (2. ábra, B). Az egyes kristályok két növekedési fronttal rendelkeznek, a középvonalra általában szimmetrikusan helyezkednek el (3. ábra, C). A típusra jellemzô szövet rostos szemcsékből áll, amelyek nagy hossz/ szélesség aránnyal rendelkeznek. A mellékkőzet felé haladva a növekedési verseny erôsen elfojtott. Bons et al. (2012) 
szerint a kristályok növekedése egy szinte zárt felületen történik a középvonaltól a mellékkőzet falai felé. A növekedési verseny hiánya szintén egy keskeny kezdeti repedés jelenlétére utal. A kezdeti repedésben kialakul az uralkodóan tömeges, tömbös megjelenésú kristályokból álló középvonal, amelynek továbbnövekedéseként fejlődnek a rostos megjelenésú kristályok. A rostok követik a felnyílás pillanatnyi irányát (3. ábra,
C), mivel a kristályok növekedési síkja szükségszerúen felveszi a mellékkőzet alakját, majd a kristályok ezen a rendellenes felületen terjeszkednek tovább. A felnyílási pálya követhetôségét csökkentheti (vagy meg is szüntetheti), ha a felnyílás sebessége nagyobb, mint a kristályosodásé (HILGERS et al. 2001). Az antitaxiális szövet diffúziós anyagtranszportfolyamatra enged következtetni (BoNs 2000).
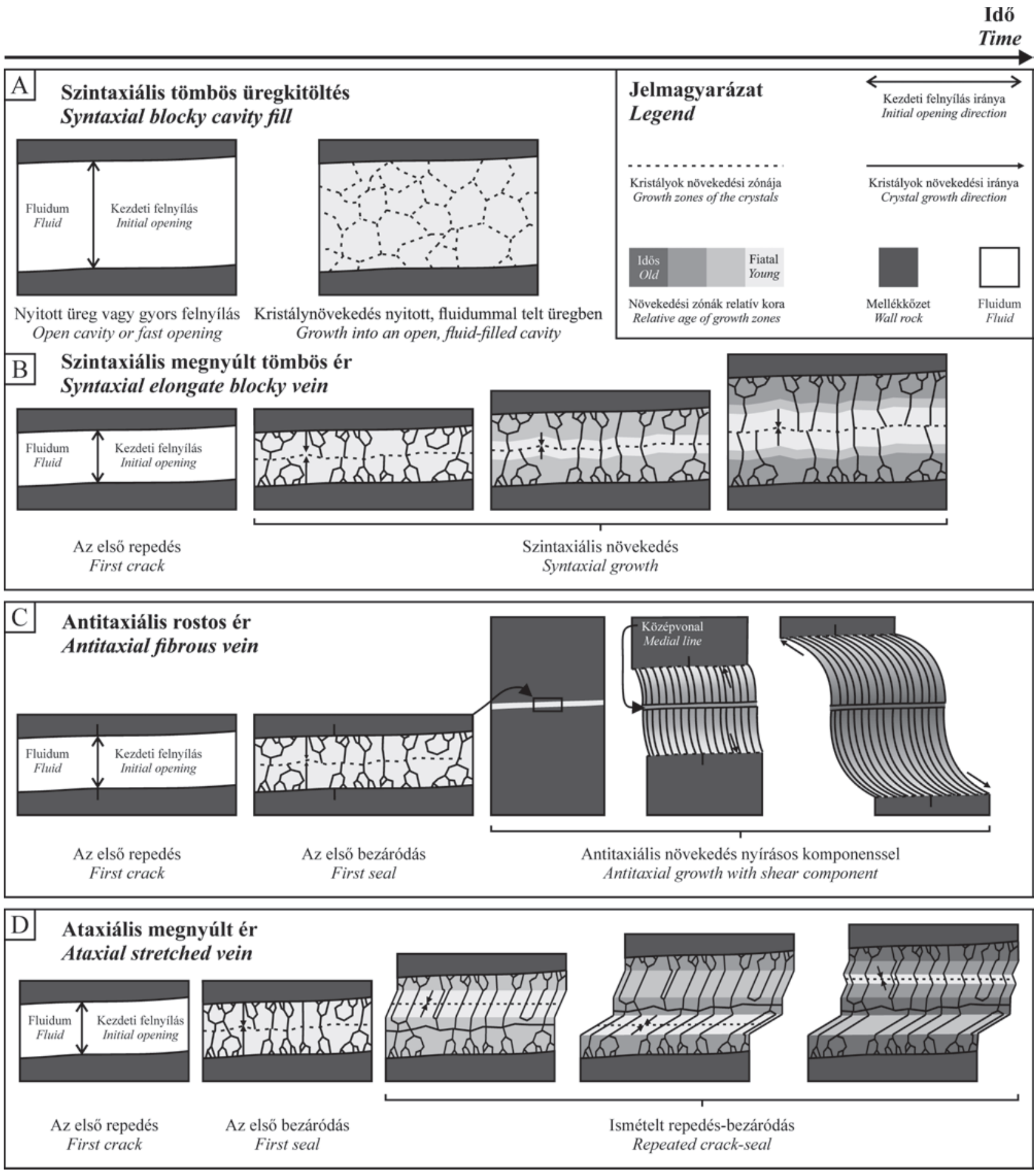

3. ábra. Eltérő értípusok fejlődésének lépései (BoNs et al. 2012 nyomán). A - szintaxiális tömbös üregkitöltés; B - szintaxiális megnyúlt tömbös ér; C - antitaxiális rostos ér; D - ataxiális megnyúlt ér

Figure 3. The steps of different vein developments (based on Bons et al. 2012). A - syntaxial blocky cavity fill; $B$ - syntaxial elongate blocky vein; $C$ - antitaxial fibrous vein; $D$ - ataxial stretched vein 
Ataxiális növekedés a repedés-bezáródási folyamat eredményeként jöhet létre abban az esetben, ha a repedés síkja nem mindig azonos helyen jelentkezik (RAMSAY 1980): megjelenhet a mellékkőzet területén vagy a már kivált kristályok sávjában (2. ábra, $C$ ). A véletlenszerúen nyíló repedéseknek köszönhetően a repedéskitöltő ásvány idősebb és fiatalabb részei a képződmény egészében változatosan helyezkedhetnek el (PASSCHIER \& TROuw 2005). A jellemző szövetet megnyúlt kristályok alkotják (3. ábra, D); zárványsorok megjelenése szintén gyakori. Az érszövet advektíven áramló szülőfluidumra utal (Bons 2000).

Az ereket kitöltő ásványtársulások szöveti fejlődéséhez — a növekedési morfológiától függetlenül — hozzájárulhat a repedések ismételt felnyílásából, és azok behegedéséből álló repedés-bezáródási (crack-seal) folyamat is (RAMSAY 1980).

Munkánkban a BAF-2 fúrás repedéskitöltéseinek szöveti leírása és értelmezése során rögzítettuik az ereket alkotó kristályok jellemző morfológiáját, definiáltuk az azokat kialakító növekedési mechanizmusokat, valamint következtettünk a kristályokat alkotó komponensek transzportfolyamatainak módjára. Mindezek alapján célunk egy új, eddig háttérbe szorult szemszögből megismerni a BAF repedéscementáció és szerkezetfejlődés történetét.

\section{Földtani háttér}

A felsố-permi BAF a Dél-Dunántúlon, a NyugatiMecsek területén és környezetében ismert (1. ábra). Felszíni előfordulásán túl az uránérc bányászatához kapcsolódó érc-, valamint szerkezetkutató fúrások tárták fel. Az elterjedési terület szerkezetileg két részre osztható, a Nyugat-mecsekiantiklinálisra (Boda-blokk), amely a BAF kiemelt helyzetú zónája, területe $55-60 \mathrm{~km}^{2}$, valamint a Gorica-blokk területére. A kettőt a Hetvehely-Magyarszéki-törés választja el egymástól (WÉBER 1977). A formáció egészének igazolt elterjedési területe 150-200 km² (BARABÁs \& BARABÁSNÉ STUHL 1998, KonRÁd \& HÁmos 2006, Halász 2011). A Boda-blokk elterjedésének határa nyugati irányban az ÉÉNy-DDK csapású Bükkösdi-törés, ahol a képződmény már lepusztult a permi feküjéről. A Gorica-blokk területén a formáció nyugati irányban fokozatosan kivékonyodik. A Boda környéki előfordulásnál a képződmény keleti irányban az antiklinális dôlése miatt, valamint a tektonikai lépcsők hatására a mélybe süllyed (KonRÁD \& HÁMOS 2006). A Keleti-Mecsek területén az igen vastag mezozoos összlet alatt a BAF jelenléte napjainkig nem igazolt. Északon a Gorica-18 fúrásig ismert az elterjedése, de az ettól északi irányban kb. 4 km-re mélyített Gálosfa-1 fúrásban ismert felsô-perm rétegek alatt sem zárható ki a jelenléte. A Gorica-blokk déli részén, valamint az antiklinálistól északra közel 2 km mélységbe süllyed (VII., VIII. és XIV. szerkezetkutató fúrások), továbbá a fedô képződmények vastagságváltozásai alapján feltételezhetjük, hogy fokozatosan kivékonyodik, majd ki is ékelődik (MÁTHÉ 2015). Déli elterjedésének határa a Mecsekalja-öv. A BAF felszíni elterjedése
14-15 km²-re tehetô, előfordulása Bükkösd, Cserdi, Boda és Bakonya települések közötti térségben található, változó (0$30 \mathrm{~m})$ vastagságú miocén és negyedidőszaki üledékkel fedve (BARABás \& BarabÁsNé StuHl 1998, HalásZ 2011, MátHÉ 2015). A kiemelt helyzetú egységet a kibúvási területet is érintô, ÉK-DNy-i csapású törészóna (BodaBüdöskúti-öv) két részre osztja (Kovács 1999). A BAF teljes rétegsorát a Nyugati-Mecsekben még egyetlen fúrás sem tárta fel, legnagyobb vastagságban a XV. szerkezetkutató fúrásból ( 870 m), valamint a BAF-2 ( 905 m) mélyfúrásból ismert. A Gorica-blokk legjelentősebb fúrása az Ib-4 fúrás, amely $214 \mathrm{~m}$ vastagságban tárta fel a BAF-ot, majd annak alsó, homokköves rétegeiben állt le. A formáció átlagos vastagsága Boda környékén 800-1000 m, míg a Gorica környéki előfordulás vastagsága 300-350 m (MÁTHÉ 2015).

A formáció fő́ kôzetalkotó ásványai a Nyugat-mecsekiantiklinális területén: kvarc, albit, illit \pm muszkovit (abszolút uralkodó agyagásvány), klorit, kalcit, dolomit, hematit. A kőzet járulékos alkotói: szmektit, sziderit, kaolinit, pirit, anhidrit, gipsz, barit, káliföldpát, azurit, vermikulit, kalkofil elemek szulfidjai (galenit, kalkopirit, szfalerit) (VARGA et al. 2006, MÁтHÉ 2015). A képződmény ásványos összetétel és szöveti jellegek alapján a Nyugat-mecseki-antiklinálison belül albitos (,albitfészkes”) agyagkő, albitolit, valamint aleurolit kőzettípusokra osztható (MÁTHÉ 2015), amelyben homokkő-közbetelepülések is megjelennek (BARABÁs \& BARABÁSNÉ STUHL 1998, VARGA et al. 2006). A formációra általánosan jellemző a vörösbarna kőzetszín, amely a fekvő Cserdi Formáció és a fedô Kôvágószőlősi Homokkő Formáció felé sötétebb árnyalatban jelenik meg. Az összletben 4-5 m vastag reduktív közbetelepülés jelenhet meg, amelyre sötétszürke, szürkésfekete szín jellemző. Ez a reduktív réteg az eddigi adatok alapján a formáció felsố harmadának az alján települ (MÁTHÉ 2015).

Az ásvány-kôzettani, geokémiai, valamint szedimentológiai információk alapján a képzôdmény arid-szemiarid klímán kialakuló, sekélyvízi, sós tavi környezetben képződött playa üledék (ÁrKAI et al. 2000, KonRÁD et al. 2010, MátHÉ \& VARGA 2012). Szedimentológiai vizsgálatok alapján jelentős része szoros értelemben véve nem tavi, hanem playa-iszaplapály kifejlódést képvisel (KoNRÁD et al. 2010).

A Bodai Agyagkövet érintő legfontosabb szerkezetalakulási események az alpi orogenezishez fúződnek, amelyek közül a legkorábbiak a késő-kréta során végbement, ÉNyDK-i kompresszióhoz köthetőek (BeNKovics et al. 1997, KovÁcs 1999). Mindemellett azonban nem zárhatóak ki a triász-jura passzív kontinensperemi helyzet kapcsán fennálló folyamatos süllyedés és tektonikai tagolódás, valamint a Tiszai-főegység európai kontinensről történő leválásának és a mecseki terület azt követô gyors süllyedésének hatásai sem, amelyet a Mecsekalja-övben kimutatott, feltehetôen triász és jura korú, tektonikus erek igazolhatnak (DABI et al. 2011, 2017). A krétában végbement deformáció során létrejöttek a Mecsek szerkezetének jellemző, ÉK-DNy-i tengelyú gyúrôdései (NÉMEDI-VARGA 1983), továbbá a redőtengellyel megegyező csapású balos eltolódások (MAROs et 
al. 2004), mindemellett a BAF-ban rétegpárhuzamos rátolódások keletkeztek (MAROs et al. 2000). WEIN (1967) feltételezése szerint a mozgások két ütemben zajlottak erős gyưrődést és pikkelyeződést hozva létre, melyeket hosszanti törésrendszerek kialakulása kísért. A Mecsek kainozoos szerkezetfejlődésére összetett, többfázisú tektonika jellemző a Pannon-medence szinrift és posztift fázisát, valamint a medence inverzióját illetően. A Pannon-medence kialakulása a Magura-óceán aljzatának hátráló szubdukciója során létrejövő extenziós medencefejlődés során vette kezdetét. A szinrift fázisban végbemenó balos transzpressziós eltolódások (NÉMEDI-VARGA 1983) pull-apart medencék kialakulását idézték elő a hegységet határoló északi és déli törészónák mentén (WEIN 1967). A deformáció a kőzetek az óramutató járásával megegyező irányú forgását eredményezte. Ennek következtében számos eltérő feszültségmező követte egymást (BEREGART \& CSONTOS 1988, CSONTOS \& BEREGART 1992, Fodor et al. 1999, MAros et al. 2003), amelyek mindegyike rendelkezett eltolódásos összetevővel (KoNRÁD 2012). A riftesedés utáni termikus süllyedés hatására a medencék tovább mélyültek a késô-miocén elején fennálló ÉNy-DK-i tengelyú tenziós feszültségmezőben (CsONTOS et al. 2002, MAros et al. 2004). A Mecsek és a Villányihegység kiemelkedése, azaz az inverzió a pannóniai fiatalabb szakaszában kezdődött (FoDOR et al. 1999, SEBE 2009 , KONRÁD 2012), rátolódásos eltolódásokat okozva a korábbi ÉK-DNy-i csapású balos eltolódásos zóna reaktiválódásával (MAROs et al. 2004), ÉNy-DK-i kompresszió és rá merőleges extenzió következtében (CsONTOs et al. 2002). KonRÁD \& SEBE (2010) szerint a Nyugat-mecseki-antiklinális területén a pannóniai-negyedidőszaki mozgások során a Nyugati-Mecsek egységes tömbként viselkedett, neotektonikára utaló jelek nem figyelhetőek meg, a fiatal szerkezeti mozgások a hegységperem és az elótér területére korlátozódnak.

A tektonikai események eredményeként létrejött repedéseket — az azokat kitöltő ásványparagenezisek alapján ÁRKAI et al. (2000) három fó csoportba sorolták. Nevezetesen kalcit-, barit-kvarc-, valamint anhidrit-domináns repedéseket határoztak meg, ahol a barit-kvarc-domináns típushoz szulfidásványok megjelenése társul. Stabilizotópos, valamint fluidumzárvány vizsgálataik alapján a barit-kvarc értípus $\sim 150{ }^{\circ} \mathrm{C}$ hőmérsékletû, magmás eredetû szülőfluidumból vált ki, míg a kalcit-domináns értípus $\sim 70{ }^{\circ} \mathrm{C}$ hőmérsékletű, meteorikus eredetű szülőfluidumhoz köthető. LENTI et al. (2010) fluidumzárvány vizsgálatai az Alfa-1 vágatból származó barit-kalcit ereket érintették. A mikrotermometriai mérések alapján kis sótartalmú (3,2-4,3 $\mathrm{m} / \mathrm{m} \% \mathrm{NaCl}$ equiv.) vizes oldat csapdázódott. A bezáródási hőmérséklet minimuma $105-107{ }^{\circ} \mathrm{C}$, míg a formáció által elért maximális hőmérséklet $177{ }^{\circ} \mathrm{C}$. A fluidumzárványok hidrotermás eredetû szülőfluidumra utalnak.

A BAF-2 fúrás 2014-ben mélyült, a Nyugat-mecsekiantiklinális területén (4. ábra), Bodától DNy-ra (KONRÁD et al. 2016). A fúrás felső 9,1 m-es szakaszában negyedidőszaki képződményeket harántolt $(0,00-0,70$ m holocén talaj, 0,70-9,10 m pleisztocén lösz, talajosodott lösz, valamint ka-

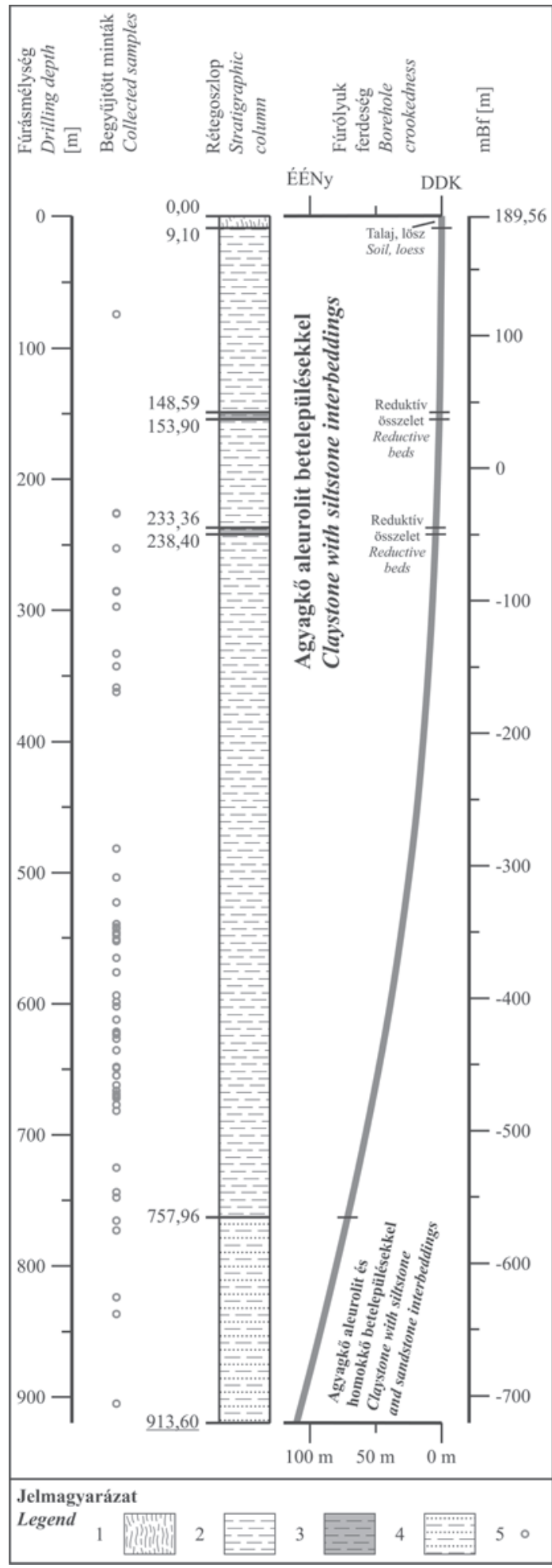

4. ábra. A BAF-2 fúrás rétegsora a fúrás ferdeségének és a begyűjtött minták mélységének feltüntetésével (KoNRÁD et al. 2016 nyomán)

1 - talaj, lösz; 2 - agyagkő aleurolit betelepülésekkel; 3 - zöldesfekete reduktív agyagkő; 4 - agyagkő aleurolit és homokkő betelepülésekkel; 5 begyüjtött fúrómag minta

Figure 4. Stratigraphical column of BAF-2 well with the borehole crookedness and with the depth of the collected core samples (based on KONRÁD et al. 2016)

1 - soil, loess; 2 - claystone with siltstone interbeddings; 3 - greenish-black reductive claystone; 4 - claystone with siltstone and sandstone interbeddings; 5 - collected core sample 
vicsos agyag). A 9,10-17,30 m közötti szakaszban morzsalékosan széteső formában jelenik meg a BAF. 757,96 m mélységig aleurolitrétegeket tartalmazó, vörösbarna agyagkő követhető, amelybe két alkalommal zöldes színú, reduktív összlet települ (148,59-153,90 m, valamint 233,36238,40 m szakaszokban). 757,96 m mélységben jelenik meg az elsô flázeres aleurolit-homokos aleurolitréteg. A fúrás talpáig (913,60 m) ez a képződmény észlelhető (KoNRÁD et al. 2015). A fúrás összesen 904,5 m vastagságban tárta fel a Bodai Agyagkövet, melyből a képződmény korrigált, valódi vastagsága $564 \mathrm{~m}$. A rétegdólés iránya uralkodóan DDKDK-i, a rétegdőlések szöge igen változó. A fúrásban kompresszióra utaló tektonikai adatok jellemzők, a megjelenő vetôk 44\%-a feltolódás vagy feltolódásos oldaleltolódás, 25\%-a oldaleltolódás, azonban mindössze 31\%-a normál vető vagy normál összetevőjú oldaleltolódás, továbbá két különböző léptékú redőződés is megmutatkozik (KoNRÁD et al. 2016). A fúrás szerkezetföldtani adatai három tektonikai fázist jeleznek (KonRÁD et al. 2015, 2016). Időrendben az elsô egy ÉNy-DK-i kompressziós esemény, amely kis hullámhosszúságú redőket, réteglap menti feltolódásokat hozott létre. Ezzel egy időben vagy ugyanezen esemény későbbi folyamataiként nagyobb hullámhosszúságú redők, illetve jelentősebb feltolódások jöttek létre. Mindezek mellett az összlet DK-i irányba billent. Ezt követően a második fázisban a meredekké váló réteglapok mentén feltolódásos összetevőjû eltolódások jöhettek létre transzpressziós feszültségmezőben. A harmadik elkülönített tektonikai fázis során, egy újabb kompressziós feszültségmező feltolódások kialakulását idézte elő, valamint feltehetően a hegység kiemelkedésekor a magasabban elhelyezkedô zónák fellazultak, a törések felnyíltak (KonRÁD et al. 2015). A D-5 és D-6 fúrásokban végzett billenéstesztek alapján (MAROs et al. 2000) a meghatározott feszültségmezók nagy része a BAFra annak mai helyzetében volt hatással, amelynek értelmében a szerkezeti elemek dőlésszögének meghatározásakor feltételeztük, hogy a repedéskitöltések kialakulása a rétegek kibillenését követően történt.

\section{Vizsgálati módszerek, mintagyưjutés}

A minták begyújtését a BAF-2 fúrás kiterített, teljes fúrómaganyaga több napos, részletes dokumentációja alapján végeztük el, amely során a domináns repedéseket, repedéskitöltéseket vizsgáltuk. A magszemle alapján $56 \mathrm{db}$, a makroszkóposan elkülöníthető értípusokat magába foglaló, egyenként 15-40 cm hosszúságú fúrómagot választottunk ki a 74,34-899,22 m-es mélységtartományból (I. melléklet).

A minták begyújtését követően elkészítettük az összes rendelkezésre álló fúrómag magszkenneres fotódokumentációját, amely lehetőséget adott számos ér dőlésszögének pontos meghatározására. A fotódokumentálás TóTH (2016) módszerével, saját fejlesztésú magszkennerrel történt a Szegedi Tudományegyetem Ásványtani, Geokémiai és Kőzettani Tanszékén. A magszkenner a 6,25 cm átmérőjű fúrómagokról 9 cm hosszúságú szakaszonként a teljes hengerfelületet $11 \mathrm{db}$ felvétel során rögzítette. Ilyen módon a fúrómagpalástok összeillesztett felvételei a minták hosszától függően 11-77 db, 15 megapixeles fényképből tevődtek össze. A fényképek Canon D60 típusú fényképezőgéppel készültek, $300 \mathrm{~mm}$ fókusztávolság, f/11 rekesz, 1/6 s expozíciós idő, ISO-100 érzékenység és manuális fókusz beállítások mellett. A részletfotók összeillesztése Autopano Giga 4.0 szoftverrel történt. A fúrómagpalást felvételek értékelésével nyert adatokat a fúrás ferdeségével korrigáltuk, majd a mélység függvényében ábrázoltuk. A magszkenneres dokumentálást követően a HÁMOs (1997) által bevezetett, majd MAROs et al. (2000) által módosított nevezéktan (5. ábra) alapján kategorizáltuk a begyújtött mintákban megjelenő töréseket és ereket. Kitértünk továbbá a repedéskitöltések vastagságának meghatározására, valamint a metsződési viszonyok feltárására is.

A makroszkóposan elkülöníthető töréstípusokat tartalmazó reprezentatív kôzetmintákból standard 30 um vastagságú vékonycsiszolatokat készítettünk a repedések felnyílási síkjára merôleges orientációban. A petrográfiai mikroszkópos vizsgálat során kitértünk a repedéskitöltő ásványfázisok meghatározására, az erek szöveti és mikroszerkezeti jellegzetességeinek megállapítására, a szemcsék morfológiai jellemzésére, valamint a kristályok növekedési morfológiájának leírására. Az ereket felépítő ásványfázisok jelölésére a SiIvOLA \& SCHMID (2007) által javasolt rövidítéseket alkalmaztuk. A repedéskitöltő fázisok leírásakor Bons (2000) szövetmorfológiai kategóriáit használtuk. A vizsgálatokat a Szegedi Tudományegyetem Ásványtani, Geokémiai és Kőzettani Tanszékén Olympus BX41 típusú polarizációs, illetve Olympus SZX7 típusú sztereomikroszkóppal végeztük. A felvételeket a mikroszkópokra szerelt Olympus DP73, valamint Olympus UC30 típusú kamerákkal készítettük. A kérdéses repedéskitöltő ásványok azonosítását THERMO DXR Raman mikrospektroszkópia segítségével végeztük. Az expozíciós időt mérésenként az automatikus mintafelvételezés során elért, 100 jel/zaj arány határozta meg. Az alkalmazott gerjesztő hullámhossz 532 nm, a lézerteljesítmény $10 \mathrm{~mW}$, a túlyuk apertúra átmérője $50 \mu \mathrm{m}$ volt a mérések során. A kapott Raman spektumokat a RRUFF adatbázis (http://rruff.info) alapján értékeltük ki. Az egyes ásványfázisok kémiai összetételének vizsgálatát a Szegedi Tudományegyetem Ásványtani, Geokémiai és Kőzettani Tanszékén Horiba Jobin Yvonne XGT 5000 röntgenfluoreszcens spektrométer segítségével, 50 keV gyorsító feszültség, 60-90 s felvételi idő és 10 mm mérési pont átmérő paraméterek mellett végeztük.

\section{A vizsgálatok eredményei}

A eredményeket a klasszikus petrográfiai megismerés sorrendiségének megfelelően, a kézipéldány léptéktől a mikroszkópi lépték felé haladva mutatjuk be. A fúrómagokon először makroszkópos megfigyeléseket, valamint a magszkenneres felvételek felhasználásával szerkezeti elem- 
zést végeztünk. A vizsgálatok eredményeit az I. mellékletben foglaltuk össze. A törések morfológiája alapján négy töréstípust különítettünk el (jelölésük: EGY, FON, ECH, BR), valamint a kitöltések szöveti jellemzői szerint további alcsoportokat hoztunk létre (6. ábra). A makroszkópos

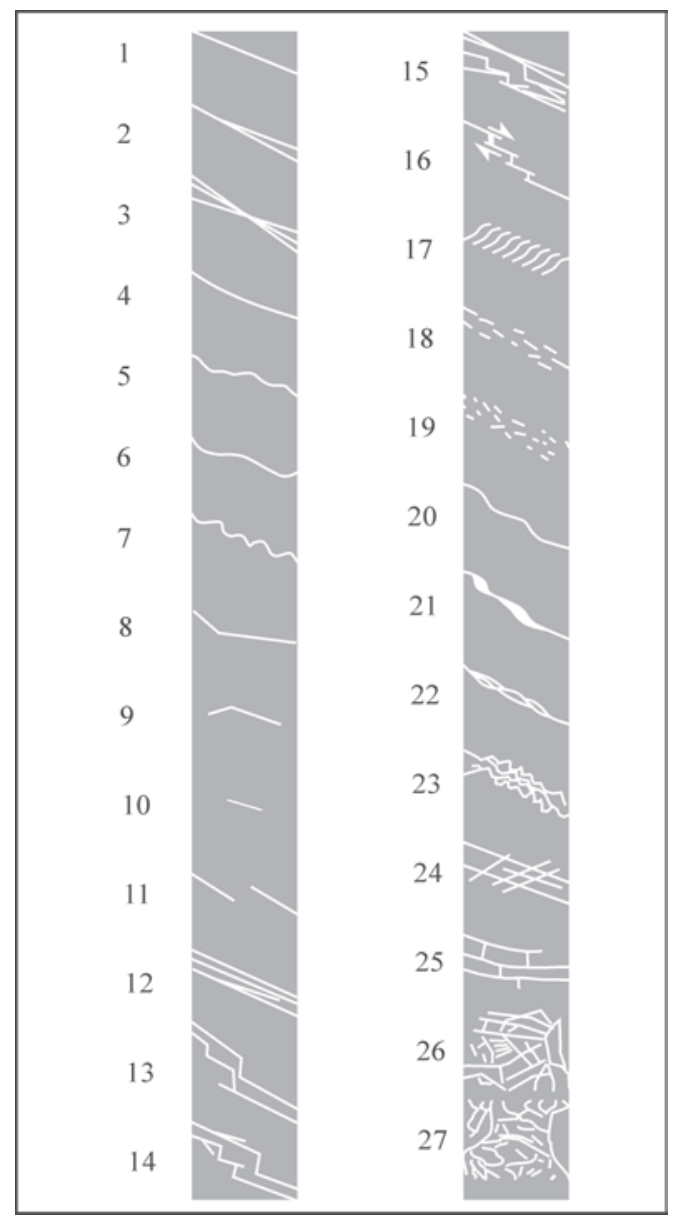

5. ábra. A Bodai Agyagkő fúrásainak tektonikai dokumentáláshoz kialakított nevezéktan (HÁmos 1997 és MARos et al. 2000 nyomán)

Jelmagyarázat: 1 - egyszerủ törés; 2 - egyszerủ törés gyenge seprőződéssel; 3 - egyszerủ törés jelentőss seprőződéssel; 4 - ives törés; 5 - szabálytalan törés; 6 - hullámos törés; 7 - recés törés; 8 - megtörö törés; 9 - megtörve elvégződő törés; 10 - elvégzỏdő törés; 11 - átlépő törés; 12 - köteges törés; 13 - lépcsős törés seprőződés nélkül; 14 lépcsős törés gyenge seprőződéssel; 15 - lépcsős törés erős seprőződéssel; 16 - pull apartos lépcsős törés; 17 - en échelon törésrendszer; 18 - megszakadó kötegekböl álló törés; 19 - mikrotörések; 20 - lépcsős törés átmenettel hajladozó törés felé; 21 - pull apart; 22 összekapcsolódó törés; 23 - fonatos törés; 24 - rombuszos törés; 25 téglarácsos törés; 26 - mozaikbreccsa; 27 - vetöbreccsa

Figure 5. Nomenclature for description of the tectonic elements during documentation of drills of Boda Claystone Formation (based on HÁMOS 1997 and MAROS et al. 2000)

1 - simple fracture; 2 - simple fracture with small diverging; 3 - simple fracture with intense diverging; 4 - arched fracture; 5 - irregular fracture; 6 - wavy fracture; 7 - jagged fracture; 8 - refracted fracture; 9 - fracture with refracted ending; 10 - ending fracture; 11 - crossing fracture; 12 fracture with fasciation; 13 - stepping fracture without diverging; 14 stepping fracture with small diverging; 15 - stepping fracture with intense diverging; 16 - stepping fracture with pull apart; 17 - en échelon arrays; 18 - fracture of discontinued fasciation; 19 - microfractures; 20 - stepping fracture transition to sinuous fracture 21 - pull apart; 22 - interconnected fracture; 23 - braided fracture; 24 - rhomboid fracture; 25 - brick-grid fracture; 26 - mosaic breccia; 27 - fault breccia vizsgálatokat követően mikroszkópos megfigyelések során ásványtani és mikroszerkezeti alapon jellemeztük a repedéskitöltéseket (7. ábra).

Az EGY típus olyan egyszerú törés, amely folytonos és lépcsősen megszakadó formában jelenik meg a mintákban. A repedéskitöltés bezáródása általában teljes, a kitöltő fehér színú ásvány kalcit (sósav hatására hevesen pezseg). A kristályos anyag általában tömött szerkezetú. Az átlagos vastagsága 1-5 mm. Számos esetben elmetszi a fonatos töréstípus kitöltését (6. ábra, $B, C$ ). A petrográfiai mikroszkópos megfigyelések alapján az egyszerú (EGY) repedéstípus kitöltésének peremi területein tömeges megjelenésú kalcit, illetve kvarc látható $\sim 100 \mu \mathrm{m}$ vastagságban. A repedéskitöltés anyagát uralkodóan antitaxiális növekedésú kalcit-, valamint anhidritkristályok alkotják, de kisebb mennyiségben Ba-tartalmú cölesztin, Sr-tartalmú barit, illetve kvarc is megjelenik (8. ábra, $A, B$ ). A megnyúlt szulfátkristályok mérete eléri a $\sim 3 \mathrm{~mm}$-t. Ezek az ásványok a gyors felnyílásból adódó nagyobb térfogat, valamint az ez okból jelentkező növekedési verseny következtében az antitaxiális növekedésre jellemzô rostos szemcsék helyett megnyúlt-tömbös alakúak. A képződményben több, egymással párhuzamos középvonal is található, amely több nagyobb felnyílási eseményre utal.

Munkánkban a FON típus fonatos felépítésú törések jelölésére szolgál. Az ezekre jellemző repedéskitöltésekben gyakran jelennek meg a mellékkőzetről leszakadt szilárd zárványok. A kitöltő ásvány jellemzően szürkésfehér színú, sósavas reakció alapján dominánsan kalcit anyagú. Az erekben esetenként $\sim 5 \mathrm{~mm}$ nagyságú pórusok jelennek meg, amelyek felületén fenn-nőtt kristályok láthatóak. A fonatos törések szöveti jellegzetességeik alapján három altípusra bonthatók. A FON ${ }_{z}$ jelölésú alcsoport fehér, illetve szürke színú, dominánsan kalcitból álló repedéskitöltés jellemzi, amely bezáródása általában teljes. A kitöltésben az alapkőzet leszakadt, elvonszolt részei hálószerúen járják át a képződményt (6. ábra, B). Az alcsoportba tartozó erek átlagos vastagsága 2-4 mm. Mikroszkópos megfigyelések alapján a $\mathrm{FON}_{\mathrm{Z}}$ töréstípus $(8$. ábra, $C$ ) repedéskitöltéseit dominánsan kalcit alkotja, de kisebb mennyiségben az ér és a mellékkőzet határán, valamint a mellékkőzetzárványok körül kisméretú $(\leq 10 \mu \mathrm{m})$ albitkristályok figyelhetôek meg (9. ábra). Az ér fejlődése számos repedés-bezáródás eseményhez köthetố. A felnyílási síkok helye - az ataxiális szövetre jellemzően (RAMSAY 1980) — a képződmény egészében véletlenszerú, az ismételt felnyílások más és más helyeken jelentkeztek mind az érben, mind a mellékkőzetben. Az uralkodó szemcsemorfológia tömbös (BoNs et al. 2012). A FON $\mathrm{L}_{\mathrm{L}}$ jelölésú alcsoport repedéskitöltése szintén fehér, illetve világosszürke kalcit, amelyben kisméretú pórusok jelennek meg $(6 . a ́ b r a, C)$. A pórusok falán a jó hasadás (pátos halmazok) alapján feltételezhetően szulfátásványok jelennek meg. Az alcsoportba sorolt erek átlagos vastagsága 2-9 mm. Mikroszkópos vizsgálatok szerint a repedéskitöltést uralkodóan kalcitkristályok alkotják, de alárendelten albit, valamint cölesztin is megjelenik. Az érmellékkőzet határ közelében nem definiálható jól a szem- 

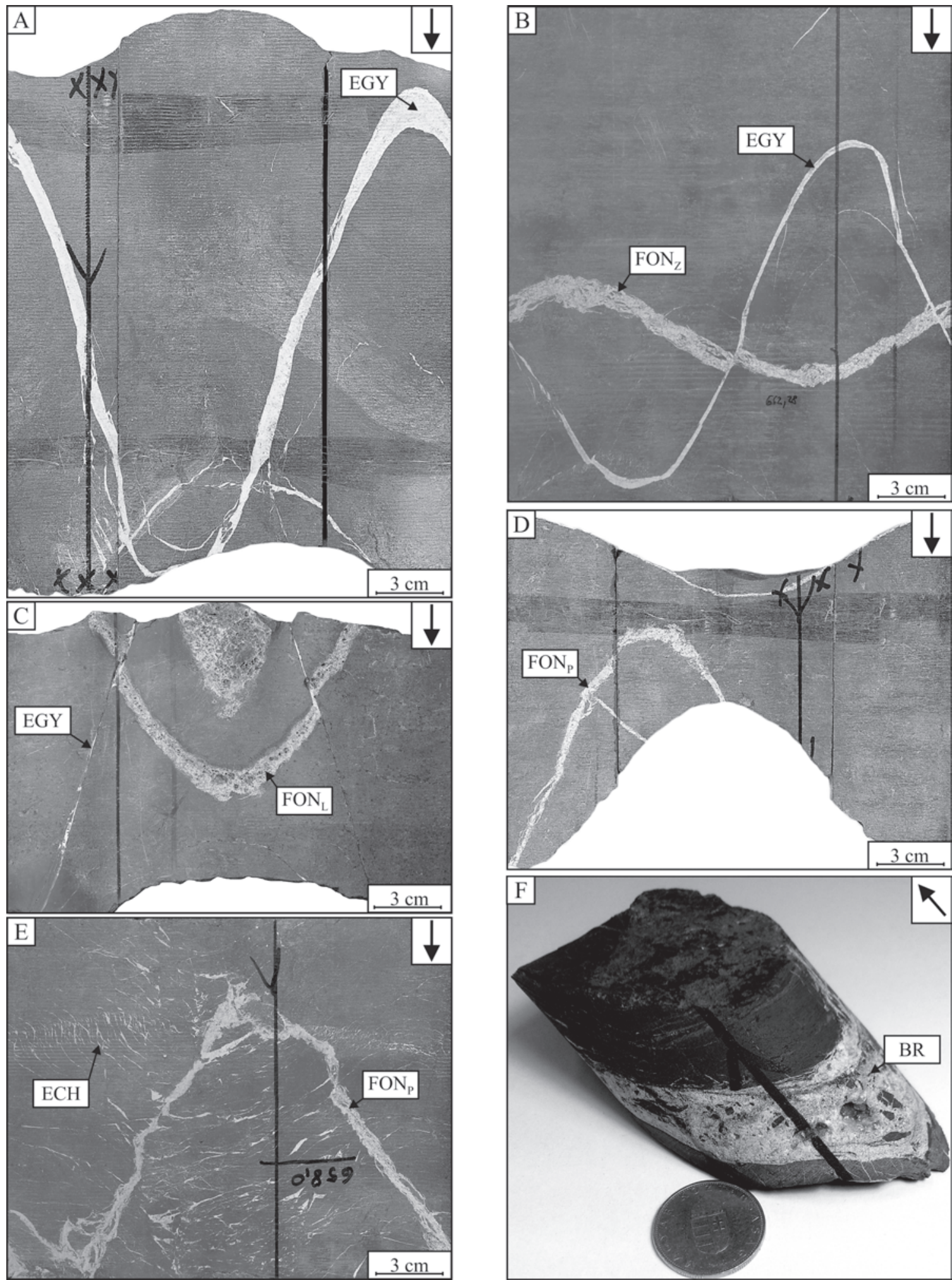

6. ábra. A fúrómag mintákon azonosított töréstípusok és kitöltésük. A - egyszerủ törés teljes kitöltéssel; B - fonatos törés mellékkőzettel átjárt repedéskitöltése; $\mathrm{C}$ - fonatos törés pórusokat tartalmazó kitöltéssel; $\mathrm{D}$ - fonatos törés makroszkóposan megjelenő pirites kitöltéssel; $\mathrm{E}$ - en échelon törésrendszer; F - tektonikus breccsa. Az A, B, C, D és E ábrák magszkennerrel készitett hengerpalást felvételek. A fúrómagokon lévổ fekete vonalak a magtengelyt-, a nyilak a fúrás talpát-, míg az X jelölések a fúrás során létrehozott töréseket jelzik. Az ábrák jobb felső sarkában lévő nyilak szintén a magtengelyt és a fúrás talpát mutatják

Figure 6. Fracture types and their fillings identified on drill core samples. A - simple fracture with full filling; $B$ - braided fracture with wall rock inclusions; $C$ - braided fracture with macropore permeated filling; $D$ - braided fracture with macroscopic pyrite-bearing filling; $E$ - en échelon vein arrays; $F$ - tectonic breccia. A, B, C, D and E are stitched core scanner images. The black lines on the core samples indicate the core-axis, the arrows show the well bottom, and the X marks indicate the fractures created during the drilling. The arrows in the upper right corner of the figures also show the axis of the core samples and the bottom of the well 


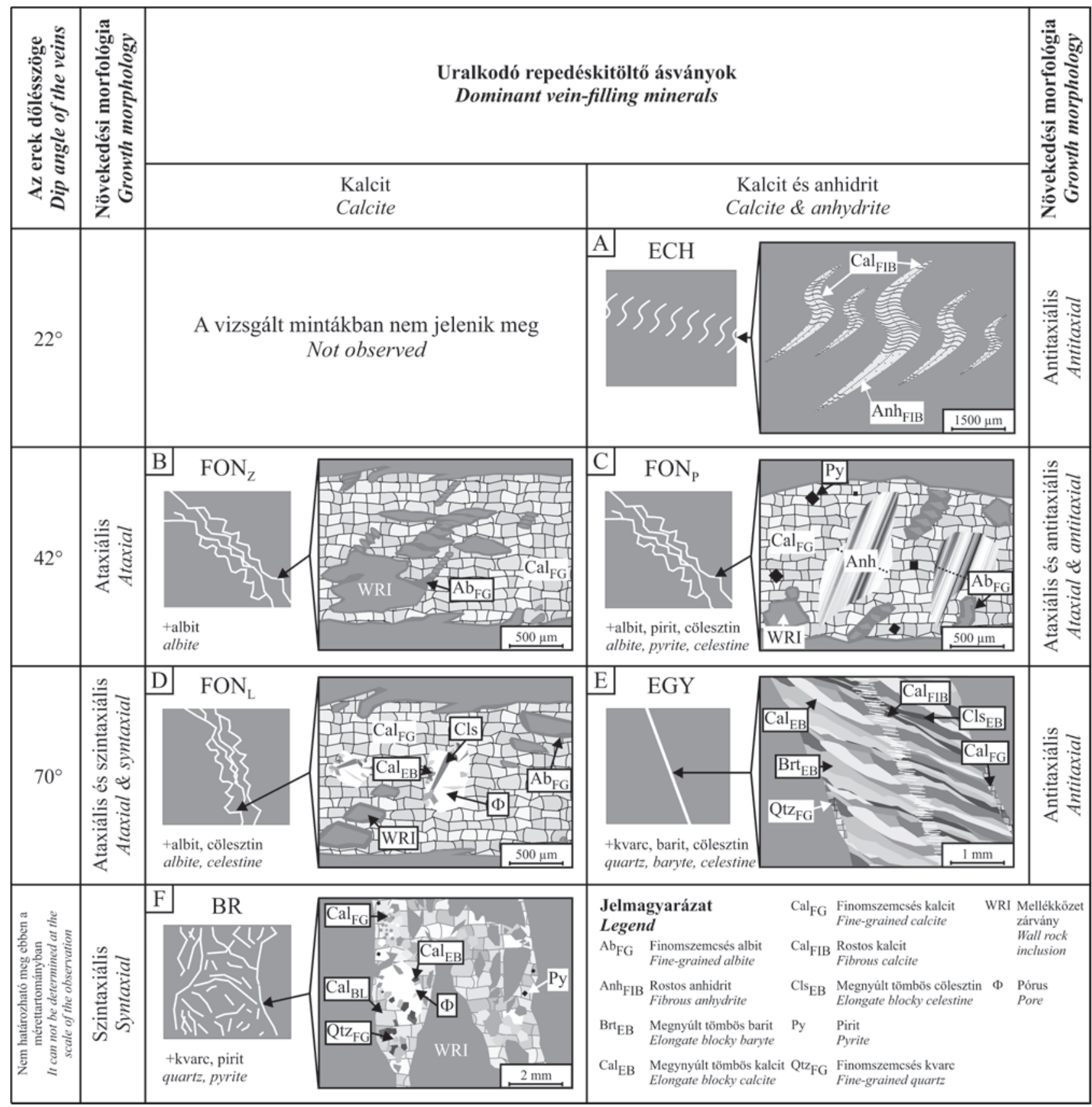

7. ábra. Repedéskitöltések jellemző mikroszövete, növekedési morfológiája és dőlésszöge. A - ECH töréstípus; $\mathrm{B}-\mathrm{FON}_{\mathrm{Z}}$ töréstípus; $\mathrm{C}$ - FON $\mathrm{N}_{\mathrm{P}}$ töréstípus; $\mathrm{D}$ FONL töréstípus; E - EGY töréstípus; F - BR töréstípus

Figure 7. Characteristic microtexture, growth morphology and dip angle of vein fillings. $A$ - en échelon fracture type; $B-F O N_{z}$ fracture type; $C$ - FON $N_{p}$ fracture type; $D$ $F O N_{L}$ fracture type; $E$ - EGY fracture type; $F$ - BR fracture type

csék növekedési morfológiája, ezeken a területeken számos, a mellékkőzet falával megegyező irányítottságú kőzetzárvány található $(8$. ábra, $D)$. A felnyílási síkok helyzete a szövetet kialakító, ismétlődő felnyílás-bezáródás során változott. Az érfalat, valamint a mellékkőzetzárványokat albitkristályokból álló perem veszi körül. A repedéskitöltés belsô zónáit tömeges, tömbös kalcit kristályai alkotják, amelyek mérete nem haladja meg a $200 \mu \mathrm{m}$-t. Az itt elhelyezkedő pórusok falán szintaxiális növekedésû kristályok láthatóak, amelyek nem töltik ki teljesen a rendelkezésre álló teret. Ezek a kristályok 700-800 m méretúek, tömbös, megnyúlt-tömbös (kalcit) és tûs (cölesztin) morfológiával rendelkeznek (10. ábra, A). A FON ${ }_{\mathrm{P}}$ altípus repedéskitöltése uralkodóan szürkésfehér kalcit, amelyben szintén sok mellékkőzet-zárvány található, valamint makroszkóposan pirit van jelen nagyobb mennyiségben. Az erek átlagos vastagsága 3-9 mm. A repedéskitöltés bezáródása általában teljes, azon belül makropórusok nem figyelhetőek meg (6. ábra, $D)$. Mikroszkópos vizsgálatok alapján a töréstípus repedéskitöltését uralkodóan tömegesen megjelenő kalcit, illetve alárendeltebb mennyiségben anhidritkristályok alkotják (10. ábra, B). Albit, pirit és cölesztin jelenléte szintén kimu- 

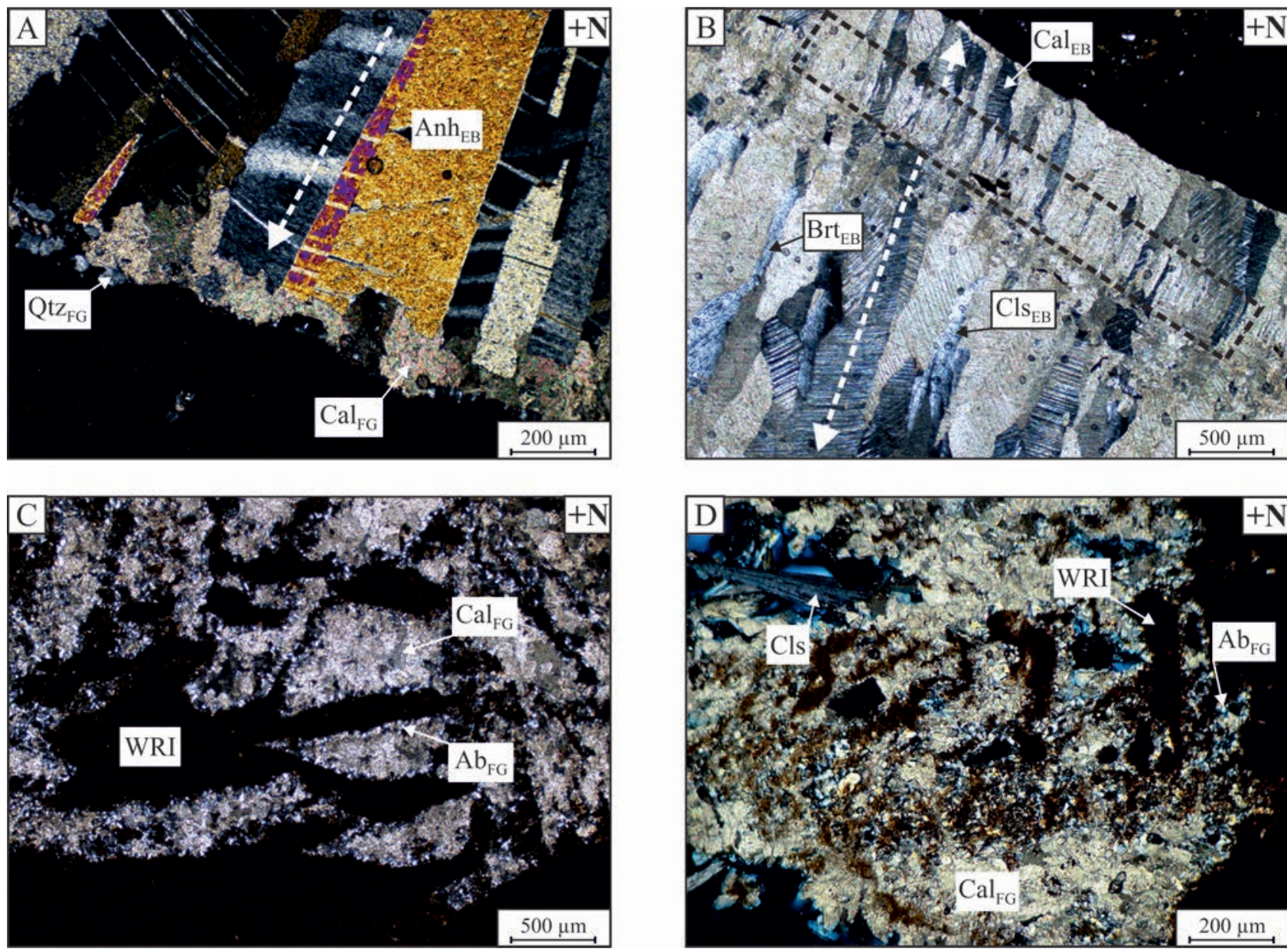

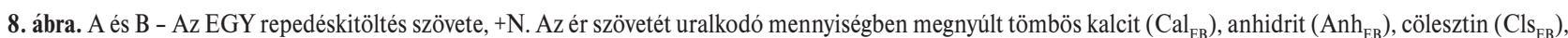
illetve barit $\left(\mathrm{Brt}_{\mathrm{EB}}\right)$ alkotja. A mellékkőzet és az ér határán finomszemcsés kvarcból $\left(\mathrm{Qtz}_{\mathrm{FG}}\right)$ és kalcitból $\left(\mathrm{Cal}_{\mathrm{FG}}\right)$ álló perem figyelhetỏ meg. A fehér szaggatott nyilak a kristályok növekedésének irányát jelzik, a fekete szaggatott vonallal jelölt terület az antitaxiális szövetre jellemzỏ középvonal. C - A FON N $_{7}$ repedéskitöltés szövete, $+\mathrm{N}$. A repedést kitöltő finomszemcsés kalcit $\left(\mathrm{Cal}_{\mathrm{FG}}\right)$, illetve a mellékkőzetzárványok (WRI) határvonalában finomszemcsés albit $\left(\mathrm{Ab}_{\mathrm{FG}}\right)$ figyelhetỏ meg. D - $\mathrm{A}$ $\mathrm{FON}_{\mathrm{L}}$ repedéskitöltés szövete, $+\mathrm{N}$. A repedést kitöltő finomszemcsés kalcit $\left(\mathrm{Cal}_{\mathrm{FG}}\right)$ alkotta szövetben lévő pórusokban tủs megjelenésủ cölesztin $(\mathrm{Cls})$ figyelhető meg. A kitöltés mellékkőzetzárványokkal (WRI) sủrủn tagolt, amelyek peremén a FON értípusra jellemzően finomszemcsés albit ( $\left(b_{\mathrm{FG}}\right)$ helyezkedik el

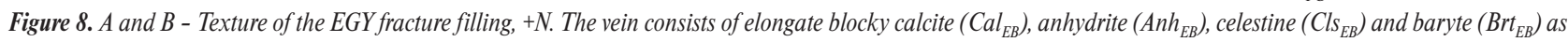
major components $(B)$. Fine-grained quartz $\left(Q t z_{F G}\right)$ and calcite $\left(C a l_{F G}\right)$ also appear at the vein boundary $(A)$. White dashed line shows the direction of crystal growth, the antitaxial medial line is indicated by black dashed line. $C$ - Texture of the $F O N_{z}$ fracture filling, $+N$. The fracture is filled with wall rock inclusion (WRI) permeated finegrained calcite $\left(\mathrm{Cal}_{F G}\right)$. Fine-grained albite $\left(A b_{F G}\right)$ rims appear around wall rock inclusions and vein boundaries. $D$ - Acicular celestine (Cls) filled pores appear in veinfilling fine-grained calcite $\left(\mathrm{Cal}_{F G}\right)$. Fine-grained albite $\left(A b_{F G}\right)$ rims appear around wall rock inclusions as well as in all FON-type veins

tatható. Az ér mellékkőzetzárványokkal sứrún szabdalt területein tömeges kalcit-, valamint a mellékkőzet peremein albitkristályok találhatóak, amelyek $100 \mu \mathrm{m}$ maximális mérettel rendelkeznek. Az ér belsố részein az egykori pórusokat kitöltô, antitaxiális növekedésú, rostos morfológiájú anhidrit-, valamint cölesztinkristályok figyelhetôek meg, amelyek mérete elérheti a $3 \mathrm{~mm}$-t. Ezeken a területeken az antitaxiális növekedésre utaló középvonal is megjelenik.

Az ECH típust kulisszás (en échelon) repedéskitöltésrendszerek jelölésére alkalmaztuk, melyek a nyírási zónákban megjelenő, egymással párhuzamos elrendeződésú, szigmoidális alakú húzási hasítékokból álló szerkezetek. Kitöltésük színe fehér, szerkezete rostos, sósavas reakció alapján dominánsan kalcit (6. ábra, E). A húzási hasítékok átlagos vastagsága 500-1500 $\mu \mathrm{m}$ közötti. Mikroszkópos megfigyelések szerint az erek szöveti fejlődése antitaxiális, azaz a kristályok növekedése a kitöltés közepe felól a mellékkőzet felé történt (10. ábra, C). Az erekben megjelenik az antitaxiális fejlődésre jellemző középvonal. A szemcsék morfológiája rostos, az egyes kristályok követik a pillanatnyi felnyílás irányát. A repedéskitöltések döntôen kalcitból állnak, azonban számos esetben anhidrit is megfigyelhetô. A két fázis egymást kiegészítve tölti ki a hasítékokat, utalva az egymással párhuzamos kifejlődésre.

A BR típus olyan breccsa jellegú repedéskitöltések csoportja (6. ábra, $F$ ), amelyeket fehér, illetve rózsaszín ásványfázisok (uralkodóan kalcit) cementálnak. A csoport elemeinek átlagos vastagsága 5-12 mm. Mikroszkópos vizsgálatok alapján a kitöltést dominánsan tömbös kalcitszemcsék alkotják, de a kalcit rostos szemcsemorfológiával is megjelenik $(10$. ábra, $D)$. Alárendelt mennyiségben tömeges megjelenésú kvarc, illetve pirit is jelen van. Az 

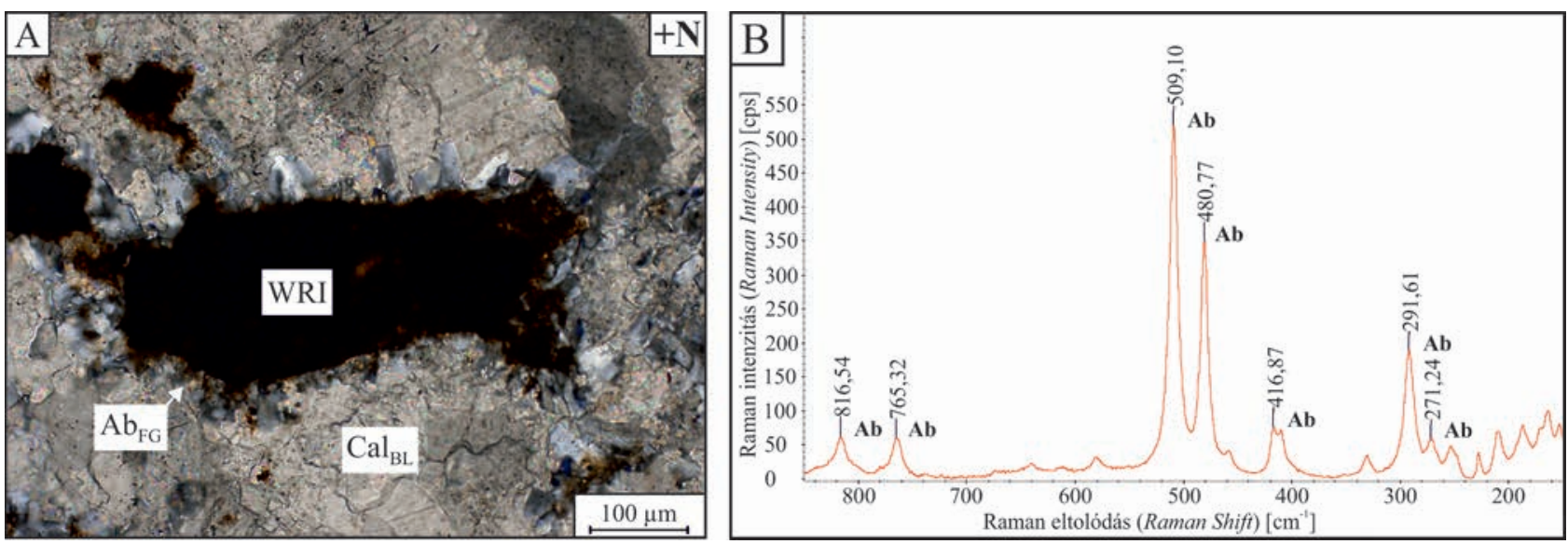

9. ábra. A - A fonatos törések kitöltésére jellemző, mellékkőzetzárványok (WRI) körül megjelenő, finomszemcsés albitperem $\left(\mathrm{Ab} \mathrm{FG}_{\mathrm{FG}}\right) \mathrm{szövete}^{+\mathrm{N}} \mathrm{B}$ - $\mathrm{A}$ fonatos repedéskitöltésekben megjelenő sajátos albitperem Raman-spektruma

Figure 9. A - The typical fine-grained albite rim around wall rock inclusions (WRI) of braided fractures $+N$. B - Raman spectra of the characteristic albite rim in braided veins
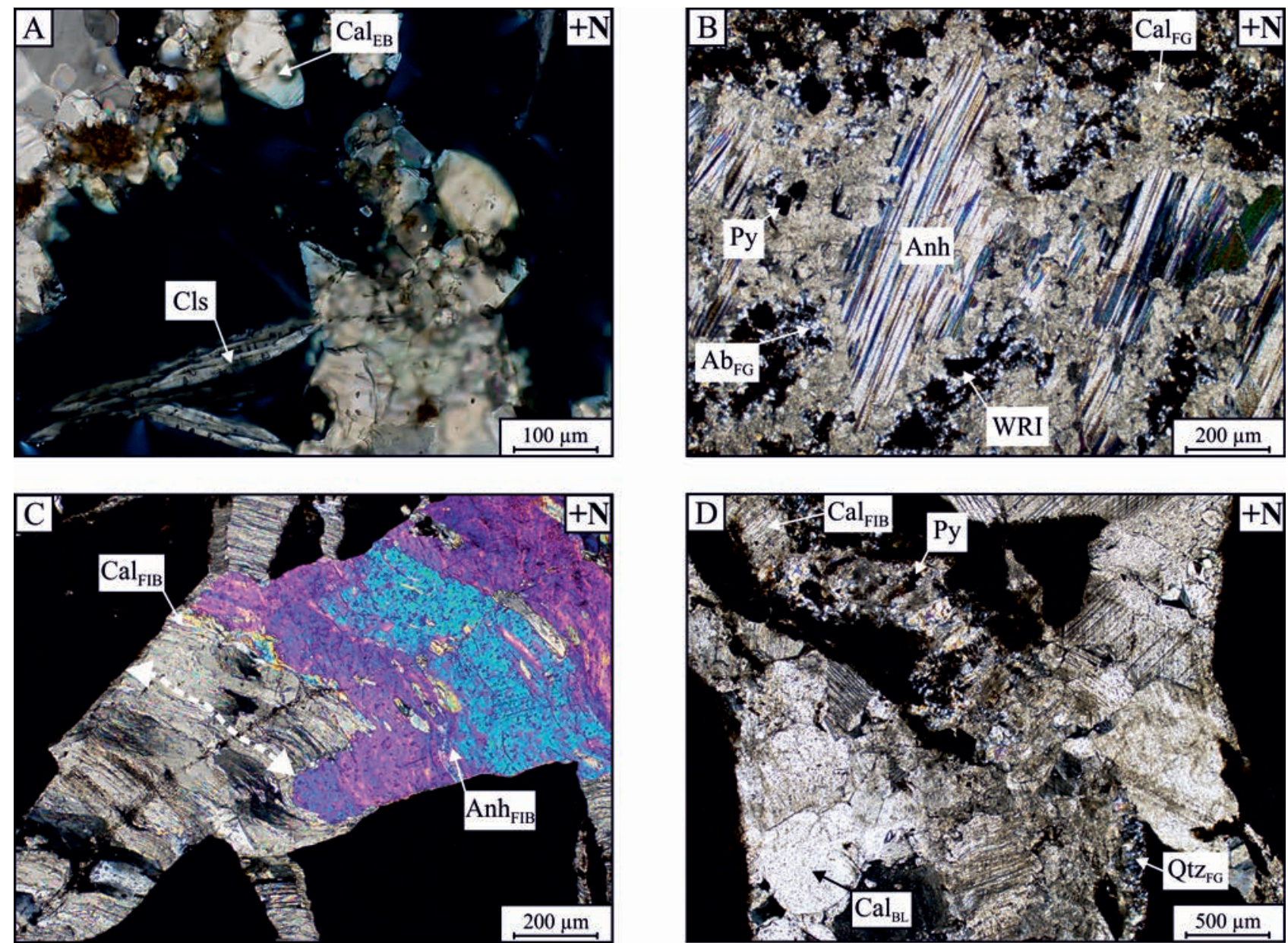

10. ábra. A - A FON $\mathrm{L}_{\mathrm{L}}$ repedéskitöltés szöveti képe, $+\mathrm{N}$. Az érszövetben megjelenő pórusok falán megnyúlt tömbös morfológiájú kalcit $\left(\mathrm{Cal}_{\mathrm{EB}}\right)$, valamint tüs cölesztin $(\mathrm{Cls})$ látható. B - A FON ${ }_{\mathrm{P}}$ repedéskitöltés szöveti képe, $+\mathrm{N}$. Az eret dominánsan mellékkőzetzárványokkal (WRI) tagolt finomszemcsés kalcit $\left(\mathrm{Cal}{ }_{\mathrm{FG}}\right)$ alkotja, amelyben kis mennyiségben pirit (Py) is megjelenik. A kitöltés belső részein antitaxiális növekedésủ anhidrit (Anh) látható. C - A kulisszás húzási hasiték szövete, $+\mathrm{N}$. A hasítékot rostos morfológiájú anhidrit $\left(\mathrm{Anh}_{\mathrm{FIB}}\right)$ és mélyebben struktúrált, szintén rostos megjelenésủ kalcitkristályok $\left(\mathrm{Cal}_{\mathrm{FIB}}\right)$ töltik ki. D - A breccsa jellegü értípus szövete, $+\mathrm{N}$. A képződményt uralkodóan blokkos kalcit $\left(\mathrm{Cal}_{\mathrm{BL}}\right)$ alkotja, azonban megjelenik finomszemcsés kvarc $\left(\mathrm{Q} \mathrm{F}_{\mathrm{FG}}\right)$, rostos morfológiájú kalcit $\left(\mathrm{Cal}_{\mathrm{FBB}}\right)$, valamint pirit $(\mathrm{Py})$ is

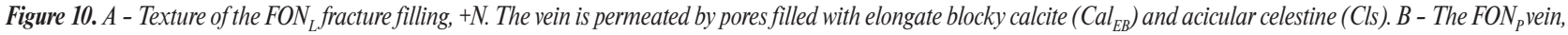
$+N$. The fracture is filled with wall rock inclusion permeated fine-grained calcite as major component and subordinate pyrite (Py). The pores in the middle zone are filled with antitaxial anhydrite $\left(\right.$ Anh). $C$ - Texture of the en échelon vein, $+N$. The vein is filled with fibrous anhidrit $\left(\right.$ Anh $\left._{F I B}\right)$ and more structured fibrous calcite $\left(C^{2} l_{F I B}\right)$. D - Texture of the breccia fracture filling, $+N$. The fracture is dominantly filled with blocky calcite $\left(\mathrm{Cal}_{B \mathrm{~S}}\right)$, with fine-grained quartz $\left(\mathrm{Qtz}_{\mathrm{FG}}\right)$, fibrous calcite $\left(\mathrm{Cal}_{\mathrm{FIB}}\right)$ and pyrite $(\mathrm{Py})$ 


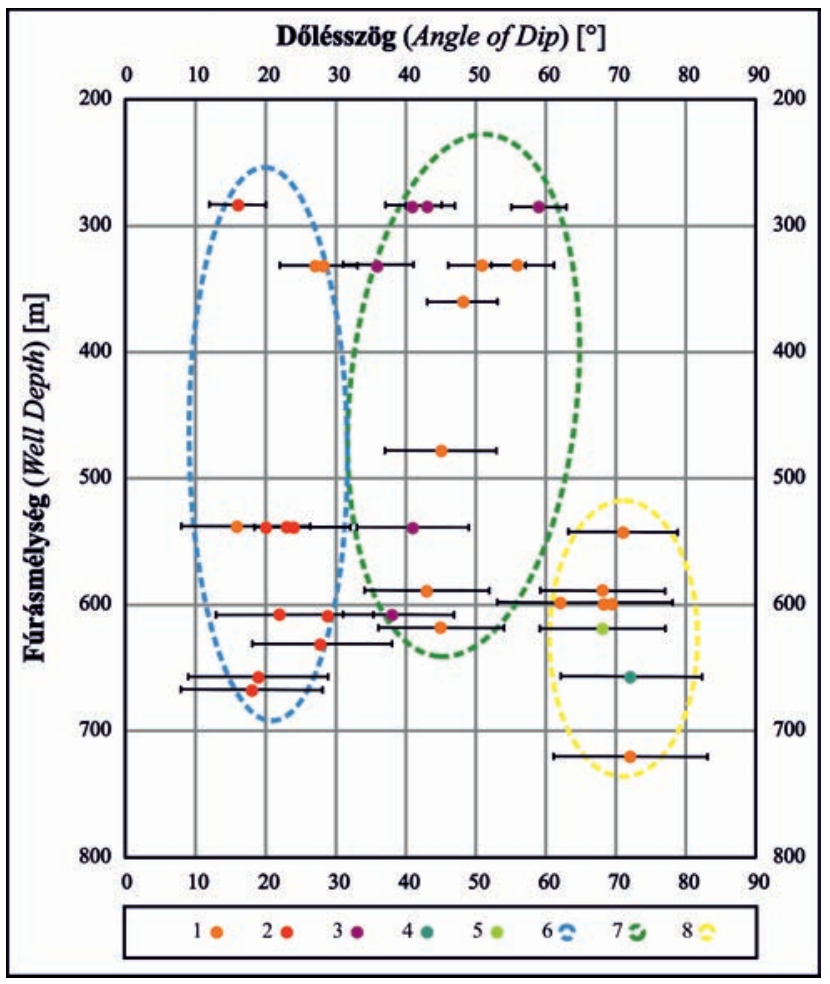

11. ábra. A repedéskitöltések fúrásferdeség adatokkal korrigált dőlésszög értékei a mélység függvényében

Jelmagyarázat: 1 - egyszerủ töréstípus teljes kitöltéssel; 2 - en échelon törésrendszer; 3 fonatos törés mellékkőzettel átjárt repedéskitöltése; 4 - fonatos törés makroszkóposan megjelenő pirites kitöltéssel; 5 - fonatos törés pórusokat tartalmazó kitöltéssel; $6-22^{\circ}$ átlagos dőlésszögủ csoport; $7-42^{\circ}$ átlagos dőlésszögủ csoport; 8 - $70^{\circ}$ átlagos dőlésszöggel rendelkező csoport

Figure 11. Calculated dip angles of the fracture fillings corrected by the measured tilt of the well

Legend: 1 - simple fracture with full filling; 2 - en échelon vein arrays; 3 - braided fracture with filling permeated by wall-rock inclusions; 4 - braided fracture with macroscopic pyritebearing filling; 5 - braided fracture with macropore permeated filling; 6 - fracture fillings with $22^{\circ}$ average dip value; 7 - fracture fillings with $42^{\circ}$ average dip value; 8 - fracture fillings with $70^{\circ}$ average dip value

érszövetben szögletes kőzetszilánkok, mellékkőzetzárványok megjelenése gyakori, amelyek jól illeszkednek egymáshoz, valamint a hasadék szegélyéhez. A cementásványok között kitöltetlen pórusok észlelhetőek, amelyek falán fenn-nôtt kalcitkristályok jelennek meg.

A képanalízissel meghatározott dőlésszögadatok három, hasonló értékekkel rendelkező kategóriába sorolhatók (11. ábra). Az első kategóriába a legkisebb dőlésszöggel rendelkező erek tartoznak, átlagos dőlésszögük $22^{\circ}$, szélsôértékei $16^{\circ}$ és $29^{\circ}$. A második csoport tagjainak átlagos dőlésszöge $42^{\circ}$, szélsőértékei $36^{\circ}$ és $51^{\circ}$. A harmadik kategória átlagos dőlésszöge $70^{\circ}$, szélsőértékei $56^{\circ}$ és $72^{\circ}$, ez utóbbi kategória mind dôlésszögében, mind mélységtartományában markánsan elkülönül a másik két csoporttól.

\section{Diszkusszió}

A fúrómagpalást-felvételek értékelése alapján az egyszerű töréstípus repedéskitöltése (EGY) mindhárom dőlésszögcsoportban gyakori. A $22^{\circ}$ átlagos dőlésszöggel rendelkező kategóriában a kulisszás húzásihasíték-rendszer jelenléte a meghatározó. A $42^{\circ}$ átlagos dőlésszögú csoportban a fonatos törés mellékkőzettel átjárt repedéskitöltése, valamint az egyszerú töréstípus domináns. A $70^{\circ}$ átlagos dőlésszögú csoportban szintén jellemzőek az egyszerú törések, azonban mellettük FON $\mathrm{L}_{\mathrm{L}}$ és $\mathrm{FON}_{\mathrm{P}}$ típusú erek is megjelennek.

A törések és erek egymáshoz viszonyított relatív kora a metszési viszonyukat figyelembe véve határozható meg (12. ábra). Az EGY típusú törések számos alkalommal elvetik a $\mathrm{FON}_{\mathrm{Z}}$ típusúakat, valamint a $\mathrm{FON}_{\mathrm{L}}$ kategóriába sorolt töréseket is, így az EGY típusú törések feltételezhetôen a $\mathrm{FON}_{\mathrm{Z}}$ és $\mathrm{FON}_{\mathrm{L}}$ típusú törések után alakultak ki. Az EGY típusú törést felülírják a kulisszás repedéskitöltés-rendszerek által kirajzolt

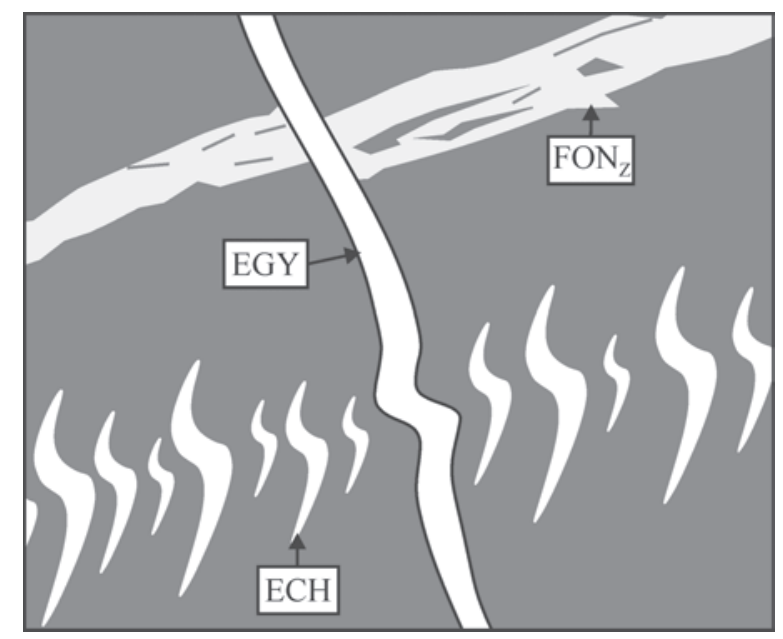

12. ábra. A repedéskitöltések legjellemzőbb metszési viszonyai

1 - $\mathrm{FON}_{Z}$ - mellékkőzetzárványokkal tagolt fonatos repedéskitöltés; 2 - EGY egyszerủ repedéskitöltés; 3 - ECH - en échelon érrendszer

Figure 12. Typical intersection relationships of the fracture fillings $1-\mathrm{FON}_{\mathrm{Z}}$ - braided fracture with wall rock inclusions permeated filling; 2 - EGY simple fracture filling; 3 - ECH - en échelon vein array

nyírási zónák, amely alapján az EGY töréstípus kialakulása az ECH nyírási zónákat megelőzően történt. Ezek az általunk legfiatalabbnak vélt szerkezeti elemek nagy valószínúséggel a pannóniai korszakot megelőzően jöttek létre (KONRÁD \& SEBE

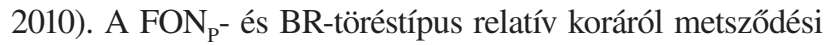
viszonyok hiányában azonban nincs információnk. A mellékkőzetzárványok és az érfalak mentén megjelenő albitkristályokból álló perem jelenléte alátámasztja a metsződési viszonyok alapján felállított koncepciót, ugyanis megjelenik a fonatos erekben, azonban az egyszerú és kulisszás repedéskitöltés típusokban már nem jelentkezik.

A szerkezeti elemek korának pontosításához kiemelendő, hogy a BAF-2 fúrás a Boda-Büdöskúti-öv szerkezeti határától D-re, a potenciális elhelyezési zóna D-i peremén mélyült, a vetôtől kb. $1 \mathrm{~km}$ távolságra. A szerkezetföldtani térképeken az öv hosszúsága 15-16 km-re becsülhető (KonRÁD \& SEBE 2010, KonRÁD et al. 2016). SCHOltz \& CowIE (1990), Kim et al. (2000) és Kim \& SANDERSON (2005) munkái alapján az eltolódások hossza (L) és a maximális elmozdulás $\left(\mathrm{d}_{\max }\right)$ között -10 km-es nagyságrendú vetôk esetén $-\mathrm{D}_{\max } / \mathrm{L}=10^{-1}$ kapcsolat áll fenn. Ennek 
értelmében a Boda-Büdöskúti-öv mentén 1,5 km-es elmozdulás is végbemehetett, ami akár azonos szélességú $(1,5 \mathrm{~km})$ kárzóna létrejöttével is járhatott (FossEN 2010). A fentiek alapján elképzelhető, hogy a BAF-2 fúrásban megfigyelt töréses szerkezeti elemek, illetve az ezekhez kapcsolódó fluidummigrációs események — legalább részben — a BodaBüdöskúti-öv mentén lezajlott, ÉK-DNy-i csapású balos eltolódások hatására alakultak ki a kréta során (MAROs et al. 2004, MAROS 2006 és az általuk hivatkozott irodalmak).

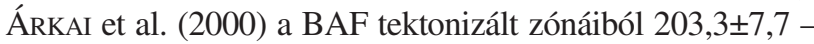
76,3 \2,9 millió éves K-Ar korokat határoztak meg. A metsződési viszonyokat, továbbá a lapos szögú rátolódásos jelleget alapul véve a BAF-2 fúrásban a legfiatalabb szerkezeti elemek, a kulisszás erek így valószínúleg a késő-kréta ÉNy-DK-i kompresszióhoz köthetôk. SEBE (2009) és KONRÁD (2012) azonban megállapították, hogy a Mecsekalja-öv mentén a kainozoikumban többször felújultak a baloldali elmozdulások — a legjelentősebb eltolódás a paleogénre valószínúsíthető, ami nem zárja ki a BAF-2 fúrásból leírt késői szerkezeti elemek és cementáló fázisok fiatalabb korát sem. A kérdés megválaszolására további vizsgálatok szükségesek.

Az azonos, vagy hasonló ásványos összetétel mellett az érpetrográfiai vizsgálatok többféle érképződési mechanizmus múködését is jelzik a BAF-2 fúrás rétegsorában. Szintaxiális növekedési morfológia a $\mathrm{FON}_{\mathrm{L}}$ és a BRértípusban jelenik meg, tömbös, megnyúlt tömbös alakú, valamint a repedések széle felől azok közepe felé növekedő ásványokkal. Ez a repedéskitöltő érszövet — a szóban forgó erek esetében — a szülőfluidum advektív áramlására utal (BONs 2000, VAN DER PluiJM \& MARSHAK 2004, DABI et al. 2009, Bons et al. 2012).
Az ataxiális növekedési morfológia igen gyakori a vizsgált mintákban, valamennyi fonatos típusú $\left(\mathrm{FON}_{\mathrm{Z}}, \mathrm{FON}_{\mathrm{L}}\right.$, $\mathrm{FON}_{\mathrm{P}}$ ) repedéskitöltésben megjelenik. A mellékkőzetzárványok orientációja alapján a kitöltéstípust gyakori, váltakozó repedés-bezáródás események hozták létre (RAMSAY 1980). Miután a felnyílási síkok véletlenszerúen jelentek meg a mellékkőzetben és a repedéskitöltés szövetében, a korai és a késôi felnyílási és cementációs események maradványai az erek területén belül változatosan helyezkednek el (PASschier \& Trouw 2005). A törések ilyen típusú kitöltései - a fentiekhez hasonlóan — szintén advektíven áramló szülőfluidumból történt kiválással jöhettek létre (BONS 2000, DABI et al. 2009).

Az ECH, valamint az EGY töréstípusok kitöltése antitaxiális érfejlődési morfológiával rendelkezik. A vizsgált erek középső részén megjelenik a középvonal, amelyben a kezdeti repedéskitöltő tömeges, tömbös alakú kristályok láthatóak. A folyamatos felnyílás következtében az egyes, immár megnyúlt habitussal rendelkező kristályok a középvonal szemcséin epitaxiális módon növekednek tovább. Az egyes szemcsék nem, vagy csak kis mértékben szélesednek a mellékkőzet felé, azaz a növekedési verseny elfojtott volt (Bons et al. 2012). A rostos kristályok követik a felnyílást, így a felnyílás iránya minden esetben kirajzolható. Az érszövet típus kialakulása feltételezhetôen diffúziós anyagáramlási folyamatok által ment végbe (Bons 2000).

A vizsgálatok során kapott eredményeket (7. ábra) az $I$. táblázatban foglaljuk össze, ahol az ÁRKAI et al. (2000) és LENTI et al. (2010) által meghatározott, a repedéskitöltésekre vonatkozó információkat is bemutatjuk. Az eredmé-

I. táblázat. A vizsgálati eredményeket összefoglaló táblázat, a korábbi munkákban (ÁRKAI et al. 2000, LENTI et al. 2010) megjelent irányadó információk feltüntetésével (n.a. - nincs adat)

Table I. Results of the microstructural, mineralogical and stitched core scanner image analyses with representation of results of previous researches (ÁRKAI et al. 2000, LENTI et al. 2010) (n.a. - no information available)

\begin{tabular}{|c|c|c|c|c|c|c|}
\hline & $\begin{array}{l}\text { Törés- } \\
\text { tipus }\end{array}$ & $\begin{array}{c}\text { Uralkodó mennyiségben } \\
\text { megjelenő repedéskitöltö } \\
\text { ásvány(ok) }\end{array}$ & $\begin{array}{c}\text { Alárendelt mennyiségben } \\
\text { megjelenö repedéskitöltö } \\
\text { ásvány(ok) }\end{array}$ & $\begin{array}{l}\text { Növekedési } \\
\text { morfológia }\end{array}$ & Átlagos dölésszög & Szülöfluidum \\
\hline \multirow{6}{*}{$\begin{array}{l}\mathrm{BAF}-2 \text { fúrás } \\
\text { reprezentatív mintái }\end{array}$} & $\mathrm{FON}_{7}$ & kalcit & albit & ataxiális & $42^{\circ}$ & n. a. \\
\hline & $\mathrm{FON}_{\mathrm{L}}$ & kalcit & albit, cölesztin & $\begin{array}{l}\text { ataxiális és } \\
\text { szintaxiális }\end{array}$ & $70^{\circ}$ & n. a. \\
\hline & $\mathrm{ECH}$ & kalcit, anhidrit & - & antitaxiális & $22^{\circ}$ & n. a. \\
\hline & EGY & kalcit, anhidrit & kvarc, barit, cölesztin & antitaxiális & $70^{\circ}$ & n. a. \\
\hline & $\mathrm{FON}_{\mathrm{p}}$ & kalcit, anhidrit & albit, pirit, cölesztin & $\begin{array}{l}\text { ataxiális és } \\
\text { antitaxiális }\end{array}$ & $70^{\circ}$ & n. a. \\
\hline & BR & kalcit & kvarc, pirit & szintaxiális & bizonytalan & n. a. \\
\hline \multirow{3}{*}{$\begin{array}{c}\text { ÁRKAI et al. (2000) } \\
\text { által publikált } \\
\text { eredmények }\end{array}$} & \multirow{3}{*}{ n. a. } & kalcit & kvarc, barit, dolomit & \multirow{3}{*}{ n. a. } & \multirow{3}{*}{ n. a. } & $\begin{array}{l}\text { meteorikus } \\
\text { eredetü, } \\
\sim 70{ }^{\circ} \mathrm{C}\end{array}$ \\
\hline & & barit-kvarc, kalcit & $\begin{array}{l}\text { dolomit, albit, klorit, } \\
\text { anhidrit, Cu-szulfidok } \\
\text { (kalkopirit, bornit, } \\
\text { kovellin) }\end{array}$ & & & $\begin{array}{c}\text { magmás eredetü, } \\
\sim 150{ }^{\circ} \mathrm{C}\end{array}$ \\
\hline & & anhidrit & $\begin{array}{l}\text { kalcit, albit, Sr-gazdag } \\
\text { barit }\end{array}$ & & & n. a. \\
\hline $\begin{array}{l}\text { LENTI et al. (2010) } \\
\text { által publikált } \\
\text { eredmények }\end{array}$ & n. a. & kalcit-barit & - & n. a. & n. a. & $\begin{array}{l}\text { hidrotermás } \\
\text { eredetü, 105- } \\
177^{\circ} \mathrm{C} \\
\end{array}$ \\
\hline
\end{tabular}


nyek alapján megállapítható, hogy a BAF-2 fúrásban megjelenő töréstípusok repedéskitöltései közül három kalcitdomináns, azonban a másodlagos repedéskitöltő ásványtársulások töréstípusonként eltérően albit, albit-cölesztin, valamint kvarc-pirit lehetnek. A vizsgált repedéskitöltések másik három típusában uralkodóan kalcit-anhidrit a domináns kitöltő ásványegyüttes, amelyek mellett másodlagosan kvarc-barit-cölesztin, valamint albit-pirit-cölesztin jelenik meg. Megállapításainkat összevetve a korábbi szakirodalmi eredményekkel elmondható, hogy az uralkodóan kalcit-, valamint anhidrit-domináns értípusok az általunk vizsgált BAF-2 mintákban is megjelennek. A harmadik korábban elkülönített csoportra, az uralkodóan barit-kvarc, kalcit együttest (ÁRKAI et al. 2000) kialakító fluidumgenerációra a kisebb mennyiségben jelenlévő kvarc-barit ásványfázisok utalnak. A repedéskitöltések szövetét és dőlésszögét figyelembe véve kijelenthetô, hogy a repedéscementációról alkotott kép összetettebb, mint azt az eddigi vizsgálatok mutatták. A megfigyelt mintákban lévố kalcit-anhidrit-domináns erekben a repedéskitöltő kristályok egyaránt előfordulnak kizárólag antitaxiális - ami lokális, diffúziós anyagáramlási folyamatokra enged következtetni —, valamint ataxiális növekedési morfológiával is, ami már egy nagyobb léptékú, advektíven áramló szülőfluidumra utal. Mindemellett az ásványtani alapon azonos értípusok mikroszerkezetükön túl dőlésszögük szerint is jelentősen eltérő kategóriákba sorolhatóak $\left(22^{\circ}\right.$ és $\left.70^{\circ}\right)$. Mindezek szerint az ásványtani alapon azonos kategóriába sorolható értípusok szövetük, valamint dőlésszögük alapján markánsan eltérô deformációs-fluidumáramlási eseményeket jelezhetnek. A kialakító folyamatok feltárására, illetve azok szerkezeti keretbe illesztésére további célzott kutatások szükségesek.

\section{Összefoglaló következtetések}

Munkánkban a BAF-2 fúrásban feltárt Bodai Agyagkőben megjelenô szerkezeti elemeket dőlésszögük szerint három kategóriába soroltuk. A dőlésszög értékeken alapuló csoportok a következők: (1) kis dőlésszögú csoport, $22^{\circ}$ átlagos dőlésszöggel; (2) közepes dőlésszögú csoport, $42^{\circ}$ átlagos dőlésszöggel; továbbá (3) nagy dőlésszögú csoport, $70^{\circ}$ átlagos dőlésszöggel. A kis- és közepes dőlésszögú csoportok szerkezeti elemei közel azonos mélységközben jelennek meg, azonban a nagy dôlésszögú csoportba tartozó repedések a fúrás alsó harmadában összpontosulnak.

A képződményben megjelenő töréseket négy csoportba osztottuk. Az erek morfológiai bélyegei alapján elkülöníthető az egyszerú törés (EGY típus), amely csoportba az általában teljes kitöltéssel rendelkező kalcit-anhidrit anyagú érgeneráció tartozik antitaxiális növekedési morfológiával, ami a legfiatalabb szerkezeti elemek egyike, fiatalabb képződmények közé biztosan csak a kulisszás erek tartoznak. Leggyakrabban a nagy dőlésszögú csoportba sorolható.

A fonatos (FON típus) csoportba olyan törések tartoznak, amelyek kitöltésében igen gyakoriak a mellékkőzet zárványai.
Ezt a típust a repedéskitöltések mikroszöveti és ásványos jellemzői alapján három további alcsoportra bontottuk. $\mathrm{A} \mathrm{FON}_{\mathrm{Z}}$ típusban a repedéskitöltó kristályok növekedési morfológiája ataxiális, a kitöltő ásvány dominánsan kalcit, kisebb mennyiségben, de jól meghatározható, jellegzetes szöveti helyzetben albit jelenik meg. Leggyakrabban a közepes dőlésszögú csoportba tartozik. Relatív időbeli sorrendben a legidősebb szerkezeti elemek közé sorolható. $\mathrm{A} \mathrm{FON}_{\mathrm{L}}$ típusban pórusok is fennmaradtak. A repedéskitöltést ataxiális, majd szintaxiális növekedésú kalcit, valamint szintén szintaxiális növekedésú cölesztin jellemzi, kis mennyiségú albittal. A FON $\mathrm{F}_{\mathrm{P}}$ típus jellegzetessége a makroszkóposan azonosítható pirit elófordulása. Repedéskitöltését dominánsan ataxiális növekedésú kalcit-, valamint antitaxiális növekedésú anhidrit és cölesztin alkotja. Kis mennyiségben albit jelenik meg.

A kulisszás (en échelon) törésrendszerek (ECH típus) szigmoidális alakú húzási hasítékrendszerekból állnak. Repedéskitöltő ásványaik antitaxiális növekedésú kalcit, illetve anhidrit. Leggyakrabban a kis dőlésszögú csoportban jelenik meg, az érszekvencia legfiatalabb képződményeként. A Mecsek hegységi analógiáknak (MAROs et al. 2000, 2004) megfelelően a kulisszás törésrendszerek kialakulása feltételezhetôen a késô-kréta ÉNy-DK-i kompresszió (BENKOvics et al. 1997) rátolódásos jellegú szerkezetalakulásához köthetô.

A breccsa (BR) töréstípus kitöltése jellemzően szintaxiális növekedésü tömbös, illetve megnyúlt tömbös kalcitból áll, kis mennyiségben kvarc, illetve pirit is megjelenik.

Eredményeink összhangban vannak a korábbi kutatások során tett ásványtani megfigyelésekkel, azonban felhívják a figyelmet arra, hogy az érkitöltések morfológiai és mikroszerkezeti vizsgálata további hasznos információkat szolgáltathat erról a kiemelt jelentőségú földtani képződményről. A kutatás során kísérletet tettünk annak bemutatására, hogy a részletes geokémiai-ásványtani vizsgálatok mintaanyagának kiválasztását megelőzôen az erek szövetének és orientációjának vizsgálata segítséget nyújthat a hasonló kitöltésú, de eltérő deformációs fázisban létrejött szerkezeti elemek elkülönítésében. Ennél fogva a repedések és az erek komplex ásványtani-geokémiai, valamint orientációs és mikroszerkezeti vizsgálata a jövőben hozzájárulhat a BAF repedéscementáció és szerkezetfejlődés rekonstrukciójához.

\section{Köszönetnyilvánítás}

Szeretnénk megköszönni a Mecsekérc Zrt-nek és a Radioaktív Hulladékokat Kezelő Közhasznú Nonprofit Kftnek, hogy lehetôvé tették a kutatás kivitelezését, valamint a BAF-2 fúrás maganyagának megtekintését és mintázását. Külön köszönjük Dr. MátHÉ Zoltánnak a munka során nyújtott szakmai segítséget és hasznos tanácsait, továbbá SÁMSON Margitnak és FöLDING Gábornak a részproblémák során nyújtott segítséget. Köszönettel tartozunk Dr. FoDOR Lászlónak, Dr. MARos Gyulának és Dr. BENKó Zsoltnak a kézirat bírálata során végzett munkájukért. A vékonycsiszolatok készítéséért BENCSIK Attilát (SZTE Ásványtani, Geokémiai és Kőzettani Tanszék) illeti köszönet. 


\section{Irodalom — References}

Árkai, P., DemÉny, A., Fórizs, I. \& MáthÉ, Z. 2000: Composition, diagenetic and post-diagenetic alterations of a possible radioactive waste repositoty site: The Boda Albitic claystone formation, southern Hungary. — Acta Geologica Hungarica 43/4, 351-378.

BARABÁs A. \& BARABÁSNé StuHL Á. 1998: A Mecsek környéke perm képződményeinek rétegtana. — In: BÉRCZI, I. \& JÁMBOR, Á. (szerk.): Magyarország geológiai képzódményeinek rétegtana. MOL Rt.—ÁFI kiadvány, Budapest, 187-215.

BÁRDossy Gy. 1995: A radioaktív hulladék elhelyezésének kérdései Magyarországon. — Magyar Tudomány 8,935-943.

BÁRDOSSY GY. 1998: A radioaktív hulladékok elhelyezése Magyarországon. — Földtani Közlöny 128/1, 179-196.

BÁRDOSSY Gy. 1999: A radioaktív hulladék hazai elhelyezésének földtudományi alapjai. — Székfoglalók a Magyar Tudományos Akadémián, MTA, Budapest, 1-31.

Benkovics, L., Mansy, J-L., Csontos, L. \& Bergerat, F. 1997: Folding in the Abaliget road cut (Mecsek Mountains). — Acta Geologica Hungarica 40/4, 425-440.

Beregart, F. \& Csontos, L. 1988: Brittle tectonics and paleostressfields in the Mecsek and Villány Mountains (Hungary): correlations with the opening mechanisms of the Pannonian Basin. - Acta Geologica Hungarica 31/1-2, 81-100.

Bons, P. D. 2000: The formation of veins and their microstructures. - Journal of the Virtual Explorer 2 , 12 p. https://doi.org/10.3809/jvirtex.2000.00007

Bons, P. D. 2001: Development of crystal morphology during unitaxial growth in progressively widening vein: I. The numerical model. - Journal of Structural Geology 23, 865-872. https://doi.org/10.1016/s0191-8141(00)00159-0

Bons, P. D., Elburg, M. A. \& Gomez-Rivas, E. 2012: A review of the formation of tectonic veins and their microstructures. - Journal of Structural Geology 43, 33-62. https://doi.org/10.1016/j.jsg.2012.07.005

Csontos, L. \& Beregart, F. 1992: Reevaluation of the Neogene brittle tectonics of the Mecsek-Villány area (SW Hungary). — Annales Universitatis Scientiarum Budapestiensis de Rolando Eötvös Nominatae, Sectio Geologica 29, 3-12.

Csontos, L., Benkovics, L., Beregart, F., Mansy, J.-L. \& Wórum, G. 2002: Tertiary deformation history from seismic section study and fault analysis in a former European Tethyan margin (the Mecsek-Villány area, SW Hungary) - Tectonophysics 357, 81-102. https://doi.org/10.1016/S0040-1951(02)00363-3

DABi G., M. Tóth T. \& SchUbert F. 2009: Eltérô szövetû́ karbonáterek szerepe a repedéscementáció rekonstrukciójában (Ófalu, Goldgrund-völgy). — Földtani Közlöny 139/1, 3-20.

DABi, G., Siklósy, Z., Schubert, F., BAJnóczy, B. \& M. Tóth, T. 2011: The relevance of vein texture in understanding the past hydraulic behaviour of a crystalline rock mass: reconstruction of the palaeohydrology of the Mecsekalja Zone, south Hungary. — Geofluids 11, 309-327. https://doi.org/10.1111/j.1468-8123.2011.00342.x

DAвi, G., Tóth, F. \& Schubert, F. 2017: Preliminary fluid inclusion microthermometry results from secondary inclusion planes crosscutting a metamorphic quartz lens from the Mecsekalja Zone metamorphic complex. - Central European Geology, 1-21. https://doi.org/10.1556/24.60.2017.006

Fedor, F., Hámos, G., Jobbiк, A., Máthé, Z., Somodi, G. \& SzỨCS, I. 2008: Laboratory pressure pulse decay permeability measurement of Boda Claystone, Mecsek Mts., SW Hungary. - Phisics and Chemistry of the Earth 33, S45-S53. https://doi.org/ 10.1016/j.pce.2008.10.059

Fodor, L., Csontos, L., Bada, G., GyÖrfi, I. \& Benkovics, L. 1999: Tertiary tectonic evolution of the Pannonian Basin System and neighbouring orogens: a new synthesis of palaeostress data. — In: Durand, B., Jolivet, L., Horváth, F. \& SÉrAnNe, M. (eds): The Mediterranean Basins: Tertiary Extension within the Alpine Orogen. Geological Society, London, Special Publications 156, 295334. https://doi.org/10.1144/gsl.sp.1999.156.01.15

Fossen, H. 2010: Structural Geology — Cambridge University Press, 463 p.

HALÁsz A. 2011: A Bodai Aleurolit Formáció ciklussztratigráfiai vizsgálata. — PhD értekezés, Pécsi Tudományegyetem, 129 p.

HÁMOS G. 1997: Földtani és bányászati kutatás a Nyugat-Mecseki antiklinális területén, a Bodai Formációnak, mint radioaktív hulladékbefogadó kőzetösszletnek az alkalmassága vizsgálatára. - Földtani Kutatás 34/3, 46-52.

HegYháti J. 2007: Radioaktív hulladékok kezelése és végleges elhelyezése. — Magyar Tudomány 167/1, 27-30.

HiLGERS, C. \& URAI, J. L. 2002: Microstructural observations on natural syntectonic fibrous veins: implications for the growth process. — Tectonophysics 352, 257-274. https://doi.org/10.1016/s0040-1951(02)00185-3

Hilgers, C., Koehn, D., Bons, P. D. \& Urai, J. L. 2001: Development of crystal morphology during unitaxial growth in progressively widening vein: II. Numerical simulations of the evolution of antitaxial fibrous veins. — Journal of Structural Geology 23, 873-885. https://doi.org/10.1016/s0191-8141(00)00160-7

KEREKI, F. 2016: Radioaktív hulladékok magyarországi kezelése és elhelyezése. — Magyar Tudomány 177/5, 518-526.

KIM, Y.-S. \& SANDERSON, D. J. 2005: The relationship between displacement and length of faults: a review. —Earth-Science Reviews 68, 317-334. https://doi.org/10.1016/j.earscirev.2004.06.003

KIM, Y.-S., ANDREWS, J. R. \& SANDERSON, D. J. 2000: Damage zones around strike-slip fault systems and strike-slip fault evolution, Crackington Haven, southwest England. — Geoscience Journal 4, 53-72. https://doi.org/10.1007/bf02910127

KONRÁD Gy. \& HÁMOS G. 2006: A magyarországi nagy aktivitású radioaktív hulladéktároló telephely kijelölésének földtani szempontjai és az eddigi kutatások eredményei. - Acta Geographica, Geologica et Meteorologica Debrecina 1, 33-39.

KonRÁD Gy. \& SEBE K. 2010: Fiatal tektonikai jelenségek új észlelései a Nyugati-Mecsekben és környezetében. — Földtani Közlöny 140/2, 135-162.

KONRÁD Gy. 2012: A Bodai Agyagkő szerkezeti helyzete, litológiája és fáciese. Környezetföldtani megközelítés. —Habilitációs tézisek, Pécsi Tudományegyetem, 9 p.

Konrád Gy., Halász A., Sebe K., Bernáth Gy., Gärtner D., Hámos G., Sámson M., MáthéZ., Óbert V., Benei B. \& Magyar L. 2016: 
A BAF-1,-1A és a BAF-2 fúrások földtani eredményei. — In: DÁlYAI V. \& HÁmos G. (szerk.): BAF Kutatás. BAF Kutatás szakmai elôadói nap kiadványa, Pécs, 39-45.

Konrád Gy., Sebe K. \& Halász,A. 2015: Földtani-tektonikai értékelés. — In: SÁMSON, M. (szerk.): BAF-2 fúrás dokumentáló és értékeló jelentése. — Kutatási jelentés, Mecsekérc Zrt. Adattára, Pécs, 119-163.

Konrád, Gy., Sebe, K., Halász, A. \& Babinszki, E. 2010: Sedimentology of a Permian playa lake: the Boda Claystone Formation, Hungary. - Geologos 16/1, 27-41. https://doi.org/10.2478/v10118-010-0002-1

KovÁCs L. (szerk.) 1999: A Bodai Aleurolit Formáció minôsítésének rövidtávú programja. Kutatási zárójelentés. Összefoglaló kötet. — Kutatási jelentés, Mecsekérc Zrt. Adattára, Pécs, 68 p.

Lenti, F., AzBej, T., NÉMETH, B. \& SzABÓ, Cs. 2010: Fluid inclusion study on the barite-calcite veins of the Boda Aleurolite Formation (Mecsek Mts., Hungary). - Acta Mineralogica-Petrographica Abstract Series 6, 201 p.

Maros Gy. 2006: A Mórágyi Gránit szerkezeti fejlődése az ImaGeo magszkennerel történt fúrásértékelések alapján. —PhD értekezés, Miskolci Egyetem, 143 p.

Maros Gy., Balla Z., Dudko A., Fodor L., Forián-Szabó M., Koroknai B., Lantos M. \& Palotás K. 2003: Az atomerőmúvi kis és közepes aktivitású radioaktív hulladékok végleges elhelyezésére irányuló program. Felszíni földtani kutatás. Tektonikai zárójelentés — Kézirat, Magyar Állami Földtani Intézet, Budapest.

Maros Gy., Koroknai B., Palotás K., Fodor L., Dudko A., Forián-Szabó M., Zilahi-Sebess L., Bánné Győry E. 2004: A Mórágyirög ÉK-i részének tektonikája és szerkezetalakulása - Tectonics and structural evolution of the NE part of the Mórágy Hills — $A$ Magyar Állami Földtani Intézet Évi jelentése 2003-ról, 371-394.

Maros Gy., Palotás K., Fodor L., Sallay E., Rálischné Felgenhauer E., Koroknai B. \& Matyikó, M. 2000: A Bodai Aleurolit Formációban mélyült D-5 és D-6 fúrások ImaGeo magszkennerrel történt értékelésének eredményei. — Kézirat, Magyar Állami Földtani Intézet, Budapest.

MÁTHÉZ. \& VARGA A. 2012: „Ízesítoô” a permi Bodai Agyagkő Formáció oskörnyezeti rekonstrukciójához: kősó utáni pszeudomorfózák a BAT-4 fúrás agyagkőmintáiban. — Földtani Közlöny 142/2, 201-204.

MátHÉ Z. 2015: A Bodai Agyagkő Formáció ásvány-kőzettani és geokémiai vizsgálata. — PhD értekezés, Eötvös Loránd Tudományegyetem, $130 \mathrm{p}$.

Mazurek, M., Pearson, F. J., Volckaert, G. \& Bock, H. 2003: Features, Events and Processes evaluation catalogue for Argillaceous Media. - Nuclear Energy Agency (NEA), Organisation for Economic Co-Operation and Development (OECD), 379 p.

NÉMEDI-VARGA Z. 1983: A Mecsek hegység szerkezetalakulása az alpi hegységképződési ciklusban. — A Magyar Állami Földtani Intézet Évi jelentése 1981-ről, 467-484.

Passchier, C. W. \& Trouw, R. A. J. 2005: Microtectonics. — Springer, 366 p. https://doi.org/10.1007/3-540-29359-0

RAMSAY, J. G. 1980: The crack-seal mechanism of rock deformation. - Nature 284, 135-139. https://doi.org/10.1038/284135a0

Scholz, C. H. \& CowIE, P. A. 1990: Determination of geologic strain from fault slip data. — Nature 346, 837-839.

SEBE K. 2009: A Nyugat-Mecsek és környezete tektonikus geomorfológiai elemzése. — PhD értekezés, Pécsi Tudományegyetem, 113 p.

SiIVOLA, J. \& ScHMID, R. 2007: A systematic nomenclature for metamorphic rocks. 12. List of Mineral Abbreviations. Recommendations by the IUGS Subcommission on the Systematics of Metamorphic Rocks. — SCMR website (https://www.bgs.ac.uk/scmr).

Tо́тн E. 2016: Szigmoidális húzási hasítékok képződési mechanizmusai és azok alkalmazási lehetőségei a nyírás mértékének becslésére a BAF-2 fúrás mintáinak példáján. - BSc szakdolgozat, Szegedi Tudományegyetem, 61 p.

VAN DER PluiJM, B. \& MARShaK, S. 2004: Earth Structure. - WW Norton \& Compan, 656 p.

Varga A., Raucsik B., Szakmány Gy. \& Máthé Z. 2006: A Bodai Aleurolit Formáció törmelékes kőzettípusainak ásványtani, koőzettani és geokémiai jellemzői. - Földtani Közlöny 136/2, 201-232.

WéBER B. 1977: Nagyszerkezeti szelvényvázlat a Ny-Mecsekből. — Földtani Közlöny 107/1, 27-37.

WeIN Gy. 1967: Délkelet-Dunántúl hegységszerkezeti egységeinek összefüggései az óalpi ciklusban. — Földtani Közlöny 97/3, 286293.

Kézirat beérkezett: 2017. 03. 26.

I. melléklet. A makroszkópos megfigyelések, valamint a magszkenneres vizsgálatok eredményei. A „Mért” feliratú oszlopban a magszkennerrel meghatározott dőlésszög értékek szerepelnek. A „Min” és „Max” oszlopokban a dőlésszög értékek fúrásferdeség adatokkal korrigált szélsőértékei láthatóak. A mintaazonosítók * szimbóluma makroszkóposan megfigyelhető piritet jelöl, (üres cella = nincs adat)

Appendix I. Results of morphological and stitched core scanner image analyses. The calculated dip angles of the veins are shown in column "Mért”. These dip values were corrected by the measured tilt of the well (shown in column „Min” and „Max”). Symbol * in the Sample ID indicates presence of macroscopic pyrite, (empty cell = no data) 


\begin{tabular}{|c|c|c|c|c|c|c|c|c|c|}
\hline \multirow{2}{*}{ Minta-azonositó } & \multicolumn{2}{|c|}{ Fúrás mélységköz } & \multirow{2}{*}{ Értípus } & \multicolumn{3}{|c|}{ Dölésszzög } & \multirow{2}{*}{$\begin{array}{c}\text { Vastag } \\
\text { ság } \\
(\mathrm{mm}) \\
\end{array}$} & \multirow{2}{*}{ Metsződés } & \multirow{2}{*}{ Bezáródás } \\
\hline & $\begin{array}{c}\text { Szakasz kezdete } \\
(\mathrm{m})\end{array}$ & $\begin{array}{c}\text { Szakasz vége } \\
(\mathrm{m})\end{array}$ & & Min. & Mért & Max. & & & \\
\hline BAF-2_074* & 74,34 & 74,45 & $\mathrm{FON}_{\mathrm{z}}$ & $46^{\circ}$ & $47^{\circ}$ & $48^{\circ}$ & $3-4$ & nincs & nem teljes \\
\hline BAF-2_224 & 224,90 & 224,94 & BR & & & & 2 & nincs & teljes \\
\hline BAF-2_225* & 225,33 & 225,40 & BR & & & & $<1-2$ & nincs & nem teljes \\
\hline \multirow{2}{*}{ BAF-2_251 } & \multirow{2}{*}{251,56} & \multirow{2}{*}{251,73} & $\mathrm{FON}_{z}$ & & & & $1-5$ & \multirow{2}{*}{$\begin{array}{l}\text { EGY elveti } \\
\text { FON }_{\mathrm{z}}-\mathrm{t}\end{array}$} & teljes \\
\hline & & & EGY & & & & $1-2$ & & teljes \\
\hline \multirow{2}{*}{ BAF-2_283 } & \multirow{2}{*}{283,90} & \multirow{2}{*}{284,14} & $\mathrm{ECH}$ & $12^{\circ}$ & $16^{\circ}$ & $20^{\circ}$ & $1-3$ & \multirow{2}{*}{ nincs } & teljes \\
\hline & & & $\mathrm{FON}_{z}$ & & & & $1-3$ & & teljes \\
\hline \multirow{3}{*}{ BAF-2_284 } & \multirow{3}{*}{284,28} & \multirow{3}{*}{284,80} & $\mathrm{FON}_{2}$ & $37^{\circ}$ & $41^{\circ}$ & $45^{\circ}$ & $1-3$ & \multirow{3}{*}{$\begin{array}{c}\text { van, } \\
\text { bizonytalan }\end{array}$} & teljes \\
\hline & & & $\mathrm{FON}_{z}$ & $39^{\circ}$ & $43^{\circ}$ & $47^{\circ}$ & $1-3$ & & teljes \\
\hline & & & $\mathrm{FON}_{z}$ & $55^{\circ}$ & $59^{\circ}$ & $63^{\circ}$ & $1-3$ & & teljes \\
\hline \multirow{2}{*}{ BAF-2_295 } & \multirow{2}{*}{295,73} & \multirow{2}{*}{295,83} & $\mathrm{FON}_{2}$ & & & & $2-3$ & \multirow{2}{*}{$\begin{array}{l}\text { EGY elveti } \\
\text { FON }-\mathrm{z}\end{array}$} & teljes \\
\hline & & & EGY & & & & 1 & & teljes \\
\hline \multirow{5}{*}{ BAF-2_331 } & \multirow{5}{*}{331,24} & & EGY & $51^{\circ}$ & $56^{\circ}$ & $61^{\circ}$ & $<1-1$ & & teljes \\
\hline & & & $\mathrm{FON}_{z}$ & $31^{\circ}$ & $36^{\circ}$ & $41^{\circ}$ & $2-3$ & & teljes \\
\hline & & 331,56 & EGY & $46^{\circ}$ & $51^{\circ}$ & $56^{\circ}$ & $<1-1$ & $\begin{array}{l}\text { EGY elvet1 } \\
\text { FON_-t }\end{array}$ & teljes \\
\hline & & & EGY & $22^{\circ}$ & $27^{\circ}$ & $32^{\circ}$ & $<1-1$ & & teljes \\
\hline & & & EGY & $23^{\circ}$ & $28^{\circ}$ & $33^{\circ}$ & $<1-1$ & & teljes \\
\hline DAC 2240 & 24082 & 24100 & $\mathrm{ECH}$ & & & & $<1-1$ & van, & teljes \\
\hline DAF -2 - 340 & 340,03 & 341,00 & EGY & & & & $2-8$ & bizonytalan & teljes \\
\hline BAF-2_356 & 356,92 & 357,12 & EGY & $43^{\circ}$ & $48^{\circ}$ & $53^{\circ}$ & $\begin{array}{l}<1- \\
10\end{array}$ & nincs & teljes \\
\hline BAF-2_360 & 360,29 & 360,45 & EGY & & & & $\begin{array}{c}<1- \\
10 \\
\end{array}$ & nincs & teljes \\
\hline BAF- 2478 & 47880 & 47800 & EGY & $37^{\circ}$ & $45^{\circ}$ & $53^{\circ}$ & $1-2$ & EGY elveti & teljes \\
\hline Din $2-710$ & 770,00 & 710 & $\mathrm{FON}_{2}$ & & & & $1-4$ & $\mathrm{FON}_{\mathrm{z}} \mathrm{-t}$ & teljes \\
\hline BAF-2_500 & 500,65 & 500,85 & $\mathrm{ECH}$ & & & & $<1-2$ & nincs & teljes \\
\hline BAF-2_519 & 519,57 & 519,82 & $\mathrm{BR}$ & & & & $\begin{array}{l}<1- \\
20 \\
\end{array}$ & nincs & nem teljes \\
\hline BAF-2 536 & 53600 & 53632 & $\mathrm{FON}_{\mathrm{z}}$ & & & & $2-5$ & EGY elveti & teljes \\
\hline DAT $=-2$ & 500,00 & J50, & EGY & & & & $1-2$ & $\mathrm{FON}_{\mathrm{z}} \mathrm{-t}$ & teljes \\
\hline & & & $\mathrm{ECH}$ & $16^{\circ}$ & $24^{\circ}$ & $32^{\circ}$ & $<1-1$ & & teljes \\
\hline & & & EGY & $8^{\circ}$ & $16^{\circ}$ & $24^{\circ}$ & $1-3$ & & teljes \\
\hline BAF-2_538a & 538,40 & 538,70 & $\mathrm{ECH}$ & $12^{\circ}$ & $20^{\circ}$ & $28^{\circ}$ & $<1-1$ & nincs & teljes \\
\hline & & & $\mathrm{ECH}$ & $15^{\circ}$ & $23^{\circ}$ & $31^{\circ}$ & $<1-1$ & & teljes \\
\hline & & & $\mathrm{ECH}$ & $15^{\circ}$ & $23^{\circ}$ & $31^{\circ}$ & $<1-1$ & & teljes \\
\hline PAF $2538 \mathrm{~b}$ & 53800 & 53005 & $\mathrm{ECH}$ & & & & $<1-2$ & EGY elveti & teljes \\
\hline ВAF-2_5380 & 500,90 & 539,05 & EGY & & & & $<1-1$ & ECH-t & teljes \\
\hline & & & $\mathrm{FON}_{z}$ & $33^{\circ}$ & $41^{\circ}$ & $49^{\circ}$ & $1-4$ & EGY elveti & teljes \\
\hline BAF-2_539a & 539,15 & 539,39 & $\mathrm{ECH}$ & & & & $<1$ & $\mathrm{FON}_{7}-\mathrm{t}$ és & teljes \\
\hline & & & EGY & & & & $1-3$ & ECH-t & teljes \\
\hline
\end{tabular}




\begin{tabular}{|c|c|c|c|c|c|c|c|c|c|}
\hline \multirow{2}{*}{ Minta-azonositó } & \multicolumn{2}{|c|}{ Fúrás mélységköz } & \multirow{2}{*}{ Értípus } & \multicolumn{3}{|c|}{ Dölésszzög } & \multirow{2}{*}{$\begin{array}{c}\text { Vastagság } \\
(\mathrm{mm})\end{array}$} & \multirow{2}{*}{ Metszödés } & \multirow{2}{*}{ Bezáródás } \\
\hline & $\begin{array}{l}\text { Szakasz kezdete } \\
(\mathrm{m})\end{array}$ & $\begin{array}{l}\text { Szakasz vége } \\
\text { (m) }\end{array}$ & & Min. & Mért & Max. & & & \\
\hline \multirow{2}{*}{ BAF-2_539b } & \multirow{2}{*}{539,41} & \multirow{2}{*}{539,84} & $\mathrm{ECH}$ & & & & $<1-1$ & \multirow{2}{*}{$\begin{array}{l}\text { EGY elveti } \\
\text { ECH-t }\end{array}$} & teljes \\
\hline & & & EGY & & & & $<1$ & & teljes \\
\hline BAF-2_542a & 542,40 & 542,58 & ECH & & & & $<1-1$ & nincs & teljes \\
\hline \multirow{3}{*}{ BAF-2_542b } & \multirow{3}{*}{542,58} & \multirow{3}{*}{542,78} & $\mathrm{FON}_{2}$ & & & & 3 & \multirow{3}{*}{$\begin{array}{l}\text { EGY elveti } \\
\text { FON }_{\mathrm{z}}-\mathrm{t}\end{array}$} & teljes \\
\hline & & & EGY & $63^{\circ}$ & $71^{\circ}$ & $79^{\circ}$ & $1-3$ & & teljes \\
\hline & & & ECH & & & & $<1-1$ & & teljes \\
\hline \multirow{3}{*}{ BAF-2_543 } & \multirow{3}{*}{543,07} & \multirow{3}{*}{543,26} & $\mathrm{ECH}$ & & & & $<1-1$ & \multirow{3}{*}{ nincs } & teljes \\
\hline & & & EGY & $63^{\circ}$ & $71^{\circ}$ & $79^{\circ}$ & $<1-2$ & & teljes \\
\hline & & & EGY & $63^{\circ}$ & $71^{\circ}$ & $79^{\circ}$ & $<1-2$ & & teljes \\
\hline \multirow{3}{*}{ BAF-2_544 } & \multirow{3}{*}{544,23} & \multirow{3}{*}{544,76} & $\mathrm{FON}_{z}$ & & & & $6-8$ & \multirow{3}{*}{$\begin{array}{l}\text { EGY elveti } \\
\text { FON }_{\mathrm{z}}-\mathrm{t}\end{array}$} & teljes \\
\hline & & & EGY & & & & $1-4$ & & teljes \\
\hline & & & $\mathrm{ECH}$ & & & & $<1-4$ & & teljes \\
\hline \multirow{2}{*}{ BAF-2_547 } & 54740 & 54750 & EGY & & & & $<1-12$ & EGY elveti & teljes \\
\hline & $34 /, 40$ & $54 /, 50$ & BR & & & & $<1-12$ & BR-t & nem teljes \\
\hline $\mathrm{BAF}-2548_{\mathrm{a}}$ & 548,40 & 54866 & EGY & & & & $<1-2$ & EGY elveti & teljes \\
\hline DAF $-2,540 \mathrm{a}$ & 340,40 & 340,00 & $\mathrm{FON}_{\mathrm{z}}$ & & & & $1-3$ & $\mathrm{FON}_{z}-\mathrm{t}$ & teljes \\
\hline BAF-2_548b & 548,85 & 548,90 & BR & & & & $10-13$ & nincs & nem teljes \\
\hline BAF $=561$ & 56158 & 56200 & $\mathrm{FON}_{\mathrm{z}}$ & & & & $1-3$ & van, & teljes \\
\hline DAT-2_-J01 & 501,50 & 502,00 & EGY & & & & $<1-1$ & bizonytalan & teljes \\
\hline & & & $\mathrm{FON}_{\mathrm{L}}$ & & & & $3-5$ & & nem teljes \\
\hline BAF-2_572 & 572,48 & 573,08 & EGY & & & & $<1-4$ & EGY elveti & teljes \\
\hline & & & ECH & & & & $<1-1$ & & teljes \\
\hline BAF 2580 & 58002 & 50006 & EGY & $59^{\circ}$ & $68^{\circ}$ & $77^{\circ}$ & $2-5$ & van, & teljes \\
\hline DAF $-2-509$ & 509,92 & 390,00 & EGY & $34^{\circ}$ & $43^{\circ}$ & $52^{\circ}$ & $<1-3$ & bizonytalan & teljes \\
\hline DAC 2504 & 50405 & 50512 & EGY & & & & $<1-1$ & in & teljes \\
\hline DAF -2 - 394 & (394, & 395,12 & $\mathrm{ECH}$ & & & & $<1$ & Hints & teljes \\
\hline & & & $\mathrm{ECH}$ & & & & $<1-1$ & & teljes \\
\hline RAF 2508 & 50825 & 50845 & EGY & $53^{\circ}$ & $62^{\circ}$ & $71^{\circ}$ & $<1-2$ & EGY elveti & teljes \\
\hline DAF -Z_J98 & 390,25 & (590,45 & EGY & $60^{\circ}$ & $69^{\circ}$ & $78^{\circ}$ & $<1-2$ & ECH-t & teljes \\
\hline & & & EGY & $59^{\circ}$ & $68^{\circ}$ & $77^{\circ}$ & $<1-2$ & & teljes \\
\hline & & & $\mathrm{ECH}$ & $13^{\circ}$ & $22^{\circ}$ & $31^{\circ}$ & $<1-1$ & & teljes \\
\hline 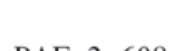 & 60000 & $600-8$ & $\mathrm{ECH}$ & $20^{\circ}$ & $29^{\circ}$ & $38^{\circ}$ & $<1-1$ & & teljes \\
\hline DAF - Z_O00 & 000,32 & 000,50 & $\mathrm{FON}_{\mathrm{z}}$ & $29^{\circ}$ & $38^{\circ}$ & $47^{\circ}$ & $5-7$ & bizonytalan & nem teljes \\
\hline & & & EGY & & & & $1-4$ & & nem teljes \\
\hline $\mathrm{DAC} 2617$ & 61745 & 61754 & $\mathrm{FON}_{\mathrm{z}}$ & & & & $3-6$ & EGY elveti & nem teljes \\
\hline BAF-2_-017 & 017,43 & 017,04 & EGY & & & & $<1-1$ & $\mathrm{FON}_{\mathrm{Z}} \mathrm{-t}$ & teljes \\
\hline & & & $\mathrm{ECH}$ & & & & $<1-2$ & & teljes \\
\hline BAF-2_618 & 618,47 & 618,57 & EGY & $36^{\circ}$ & $45^{\circ}$ & $54^{\circ}$ & $<1-3$ & nincs & teljes \\
\hline & & & BR & & & & 12 & & nem teljes \\
\hline
\end{tabular}




\begin{tabular}{|c|c|c|c|c|c|c|c|c|c|}
\hline \multirow[b]{2}{*}{ Minta-azonosító } & \multicolumn{2}{|c|}{ Fúrás mélységköz } & \multirow{2}{*}{ Értípus } & \multicolumn{3}{|c|}{ Dölésszög } & \multirow{2}{*}{$\begin{array}{l}\text { Vastagság } \\
\quad(\mathrm{mm})\end{array}$} & \multirow[b]{2}{*}{ Metsződés } & \multirow[b]{2}{*}{ Bezáródás } \\
\hline & $\begin{array}{c}\text { Szakasz kezdete } \\
(\mathrm{m})\end{array}$ & $\begin{array}{c}\text { Szakasz vége } \\
(\mathrm{m})\end{array}$ & & Min. & Mért & Max. & & & \\
\hline BAF-2_619 & 619,60 & 619,75 & $\mathrm{FON}_{\mathrm{L}}$ & $59^{\circ}$ & $68^{\circ}$ & $77^{\circ}$ & $1-10$ & nincs & nem teljes \\
\hline \multirow{2}{*}{ BAF-2_622 } & \multirow{2}{*}{622,80} & \multirow{2}{*}{622,97} & $\mathrm{FON}_{\mathrm{L}}$ & & & & $3-12$ & \multirow{2}{*}{$\begin{array}{c}\text { EGY elveti } \\
\text { FON }_{\mathrm{L}}-\mathrm{t}\end{array}$} & nem teljes \\
\hline & & & EGY & & & & $<1-2$ & & teljes \\
\hline \multirow{2}{*}{ BAF-2_631 } & \multirow{2}{*}{631,50} & \multirow{2}{*}{631,65} & $\mathrm{ECH}$ & $18^{\circ}$ & $28^{\circ}$ & $38^{\circ}$ & $<1-1$ & \multirow{2}{*}{ nincs } & teljes \\
\hline & & & EGY & & & & $<1-1$ & & teljes \\
\hline \multirow{2}{*}{ BAF-2_644a } & \multirow{2}{*}{644,00} & \multirow{2}{*}{644,25} & $\mathrm{ECH}$ & & & & $<1-1$ & \multirow{2}{*}{$\begin{array}{c}\text { EGY elveti } \\
\text { ECH-t }\end{array}$} & teljes \\
\hline & & & EGY & & & & $<1-10$ & & teljes \\
\hline \multirow{2}{*}{ BAF-2_644b } & \multirow{2}{*}{644,91} & \multirow{2}{*}{645,08} & EGY & & & & $<1-2$ & \multirow{2}{*}{$\begin{array}{c}\text { FON }_{\mathrm{p}} \text { elveti } \\
\text { EGY-t }\end{array}$} & teljes \\
\hline & & & $\mathrm{FON}_{\mathrm{p}}$ & & & & $1-15$ & & teljes \\
\hline & & & $\mathrm{ECH}$ & & & & $<1-1$ & ECH elveti & teljes \\
\hline BAF-2_650* & 650,60 & 650,74 & $\mathrm{FON}_{\mathrm{z}}$ & & & & 2 & $\mathrm{FON}_{\mathrm{z}}-\mathrm{t}$ & teljes \\
\hline $\mathrm{BAF}_{-2} 267$ & 65790 & 65805 & $\mathrm{ECH}$ & $9^{\circ}$ & $19^{\circ}$ & $29^{\circ}$ & $<1-2$ & van, & teljes \\
\hline DAI-2_- & 007,90 & 070,03 & $\mathrm{FON}_{\mathrm{p}}$ & $62^{\circ}$ & $72^{\circ}$ & $82^{\circ}$ & $2-8$ & bizonytalan & teljes \\
\hline & & & $\mathrm{ECH}$ & & & & $<1$ & & teljes \\
\hline BAF-2_662 & 662,10 & 662,40 & $\mathrm{FON}_{\mathrm{p}}$ & & & & $5-15$ & $\begin{array}{l}\text { EGY elveti } \\
\text { FON }-\mathrm{t}\end{array}$ & teljes \\
\hline & & & EGY & & & & $2-3$ & & teljes \\
\hline & & & EGY & & & & $<1-1$ & EGY elveti & teljes \\
\hline BAF-2_004 & 604,39 & $604, / 8$ & $\mathrm{FON}_{\mathrm{p}}$ & & & & $1-10$ & $\mathrm{FON}_{\mathrm{p}}-\mathrm{t}$ & teljes \\
\hline BAF-2_665 & 665,90 & 666,03 & $\mathrm{FON}_{\mathrm{p}}$ & & & & $5-9$ & nincs & teljes \\
\hline & & & $\mathrm{ECH}$ & & & & $<1$ & ECH elveti & teljes \\
\hline BAF-2_660 & $666, / 2$ & $66 /, 18$ & EGY & & & & $<1-5$ & EGY-t & teljes \\
\hline & & & $\mathrm{ECH}$ & $8^{\circ}$ & $18^{\circ}$ & $28^{\circ}$ & $<1$ & ECH elveti & teljes \\
\hline BAF-2_66/ & $66 /, 60$ & $60 /, 80$ & EGY & & & & $<1-1$ & EGY-t & teljes \\
\hline & & & $\mathrm{FON}_{\mathrm{p}}$ & & & & $3-6$ & EGY elveti & teljes \\
\hline BAF-2_672 & 672,76 & 672,89 & $\mathrm{FON}_{\mathrm{z}}$ & & & & $1-3$ & $\begin{array}{l}\mathrm{FON}_{\mathrm{p}} \mathrm{t} \text { es } \\
\mathrm{FON}_{\mathrm{r}}-\mathrm{t} \text {, }\end{array}$ & teljes \\
\hline & & & EGY & & & & $<1-1$ & $\begin{array}{c}\text { FON }_{\mathrm{p}} \text { elveti } \\
\text { FON }_{7}-\mathrm{t}\end{array}$ & teljes \\
\hline & & & $\mathrm{FON}_{\mathrm{p}}$ & & & & $2-5$ & & teljes \\
\hline BAF-2_677 & 677,31 & 677,48 & EGY & & & & $1-2$ & $\begin{array}{c}\text { van, } \\
\text { bizonytalan }\end{array}$ & teljes \\
\hline & & & $\mathrm{BR}$ & & & & 15 & & teljes \\
\hline BAF-2_720 & 720,40 & 720,63 & EGY & $61^{\circ}$ & $72^{\circ}$ & $83^{\circ}$ & $5-16$ & nincs & teljes \\
\hline BAF-2 738 & 73893 & 73915 & $\mathrm{ECH}$ & & & & & & teljes \\
\hline BAF $-2-138$ & 138,93 & 139,15 & EGY & & & & & bizonytalan & teljes \\
\hline BAF-2_742* & 742,93 & 743,14 & $\begin{array}{l}\text { FON, } \\
\text { FON, } \\
\text { FON }_{7}\end{array}$ & & & & $2-10$ & nincs & nem teljes \\
\hline BAF-2_760* & 760,45 & 760,59 & $\begin{array}{l}\mathrm{FON}_{\mathrm{p}} \\
\mathrm{FON}_{2}\end{array}$ & & & & $1-6$ & nincs & teljes \\
\hline BAF-2_767 & 767,80 & 768,00 & BR & & & & $1-10$ & nincs & nem teljes \\
\hline $\mathrm{BAF}_{-2} 818$ & 81845 & 81857 & $\mathrm{FON}_{2}$ & & & & $1-5$ & EGY elveti & teljes \\
\hline DAF-2_o10 & 010,43 & 010,91 & EGY & & & & $<1$ & $\mathrm{FON}_{\mathrm{z}}-\mathrm{t}$ & teljes \\
\hline $\mathrm{BAF}-2831$ & 831.14 & 831,30 & $\mathrm{FON}_{\mathrm{P}}$ & & & & $2-12$ & EGY elveti & teljes \\
\hline BAF-2_ס 831 & 831,14 & 831,50 & EGY & & & & $<1$ & $\mathrm{FON}_{\mathrm{P}}-\mathrm{t}$ & teljes \\
\hline BAF-2_898 & 898,97 & 899,22 & EGY & & & & $<1-2$ & nincs & teljes \\
\hline
\end{tabular}

